Article

\title{
Origin and Evolution of Ore-Forming Fluid and Gold-Deposition Processes at the Sanshandao Gold Deposit, Jiaodong Peninsula, Eastern China
}

\author{
Yazhou Liu ${ }^{1}$, Liqiang Yang ${ }^{1, *}$, Sirui Wang ${ }^{1}$, Xiangdong Liu ${ }^{1}$, Hao Wang ${ }^{1}$, Dapeng Li $^{2}$, \\ Pengfei Wei ${ }^{2}$, Wei Cheng ${ }^{2}$ and Bingyu Chen ${ }^{3}$ \\ 1 State Key Laboratory of Geological Processes and Mineral Resources, China University of Geosciences, \\ Beijing 100083, China; 3001160020@cugb.edu.cn (Y.L.); creedwang@163.com (S.W.); \\ lywhlxd@foxmail.com (X.L.); 2001180061@cugb.edu.cn (H.W.) \\ 2 Shandong Institute of Geological Sciences, Shandong Key Laboratory of Geological Processes and Resource \\ Utilization in Metallic Minerals, Key Laboratory of Gold Mineralization Processes and Resources Utilization \\ Subordinated to the Ministry of Land and Resources, Jinan 250013, China; dpengli@126.com (D.L.); \\ pfeiwei@126.com (P.W.); weiwei0208@sohu.com (W.C.) \\ 3 Sanshandao Gold Company, Shandong Gold Mining Stock Co., Ltd., Laizhou 261442, China; cbysxf@sohu.com \\ * Correspondence: lqyang@cugb.edu.cn
}

Received: 14 January 2019; Accepted: 7 March 2019; Published: 19 March 2019 updates

\begin{abstract}
The Early Cretaceous Sanshandao gold deposit, the largest deposit in the Sanshandao-Cangshang goldfield, is located in the northwestern part of the Jiaodong peninsula. It is host to Mesozoic granitoids and is controlled by the north by northeast (NNE) to northeast (NE)-trending Sanshandao-Cangshang fault. Two gold mineralizations were identified in the deposit's disseminated and stockwork veinlets and quartz-sulfide veins, which are typically enveloped by broad alteration selvages. Based on the cross-cutting relationships and mineralogical and textural characteristics, four stages have been identified for both styles of mineralization: Pyrite-quartz (stage 1), quartz-pyrite (stage 2), quartz-pyrite-base metal-sulfide (stage 3), and quartz-carbonate (stage 4), with gold mainly occurring in stages 2 and 3 . Three types of fluid inclusion have been distinguished on the basis of fluid-inclusion assemblages in quartz and calcite from the four stages: Pure $\mathrm{CO}_{2}$ gas (type I), $\mathrm{CO}_{2}-\mathrm{H}_{2} \mathrm{O}$ inclusions (type II), and aqueous inclusions (type III). Early-stage (stage 1) quartz primary inclusions are only type II inclusions, with trapping at $280-400{ }^{\circ} \mathrm{C}$ and salinity at $0.35 \mathrm{wt} \%-10.4 \mathrm{wt} \% \mathrm{NaCl}$ equivalent. The main mineralizing stages (stages 2 and 3) typically contain primary fluid-inclusion assemblages of all three types, which show similar phase transition temperatures and are trapped between 210 and $320^{\circ} \mathrm{C}$. The late stage (stage 4) quartz and calcite contain only type III aqueous inclusions with trapping temperatures of $150-230{ }^{\circ} \mathrm{C}$. The $\delta^{34} \mathrm{~S}$ values of the hydrothermal sulfides from the main stage range from $7.7 \%$ to $12.6 \%$ with an average of $10.15 \%$. The $\delta^{18} \mathrm{O}$ values of hydrothermal quartz mainly occur between $9.7 \%$ and $15.1 \%$ (mainly $10.7 \% 0-12.5 \%$, average $12.4 \%$ ); calculated fluid $\delta^{18} \mathrm{O}$ values are from $0.97 \%$ to $10.79 \%$ with a median value of $5.5 \%$. The $\delta \mathrm{D}_{\text {water }}$ values calculated from hydrothermal sericite range from $-67 \%$ to $-48 \%$. Considering the fluid-inclusion compositions, $\delta^{18} \mathrm{O}$ and $\delta \mathrm{D}$ compositions of ore-forming fluids, and regional geological events, the most likely ultimate potential fluid and metal would have originated from dehydration and desulfidation of the subducting paleo-Pacific slab and the subsequent devolatilization of the enriched mantle wedge. Fluid immiscibility occurred during the main ore-forming stage due to pressure decrease from the early stage (165-200 MPa) to the main stage (90-175 MPa). Followed by the changing physical and chemical conditions, the metallic elements (including $\mathrm{Au}$ ) in the fluid could no longer exist in the form of complexes and precipitated from the fluid. Water-rock sulfidation and pressure fluctuations, with associated fluid unmixing and other chemical changes, were the two main mechanisms of gold deposition.
\end{abstract}

Keywords: fluid inclusion; stable isotopes; gold deposition; Sanshandao gold deposit; Jiaodong 


\section{Introduction}

The Jiaodong gold province, being the largest gold producer in China, is located in the southeastern part of the North China Craton (NCC) (Figure 1) [1-4], with gold reserves above $3000 \mathrm{t}$ [5]. The gold deposits in Jiaodong Province are hosted predominantly by Late Mesozoic granitoids [6-10] and are controlled by northeast to north by northeast (NE-NNE) trending faults, making Jiaodong one of the biggest known mesothermal lode-gold provinces hosted in granitoids in the world [8]. Two styles of gold mineralization have been identified in this area: The Linglong-type and the Jiaojia-type [11]. The Linglong-type gold mineralization is characterized by single or multiple quartz veins, hosted in second- or third-order faults cutting the Mesozoic granitoids (Figure 1). The Jiaojia-type gold deposits are dominated by disseminated and stockwork-style altered ores that generally occur along major regional faults (Figure 1) [12], which are commonly surrounded by widespread hydrothermal alteration.

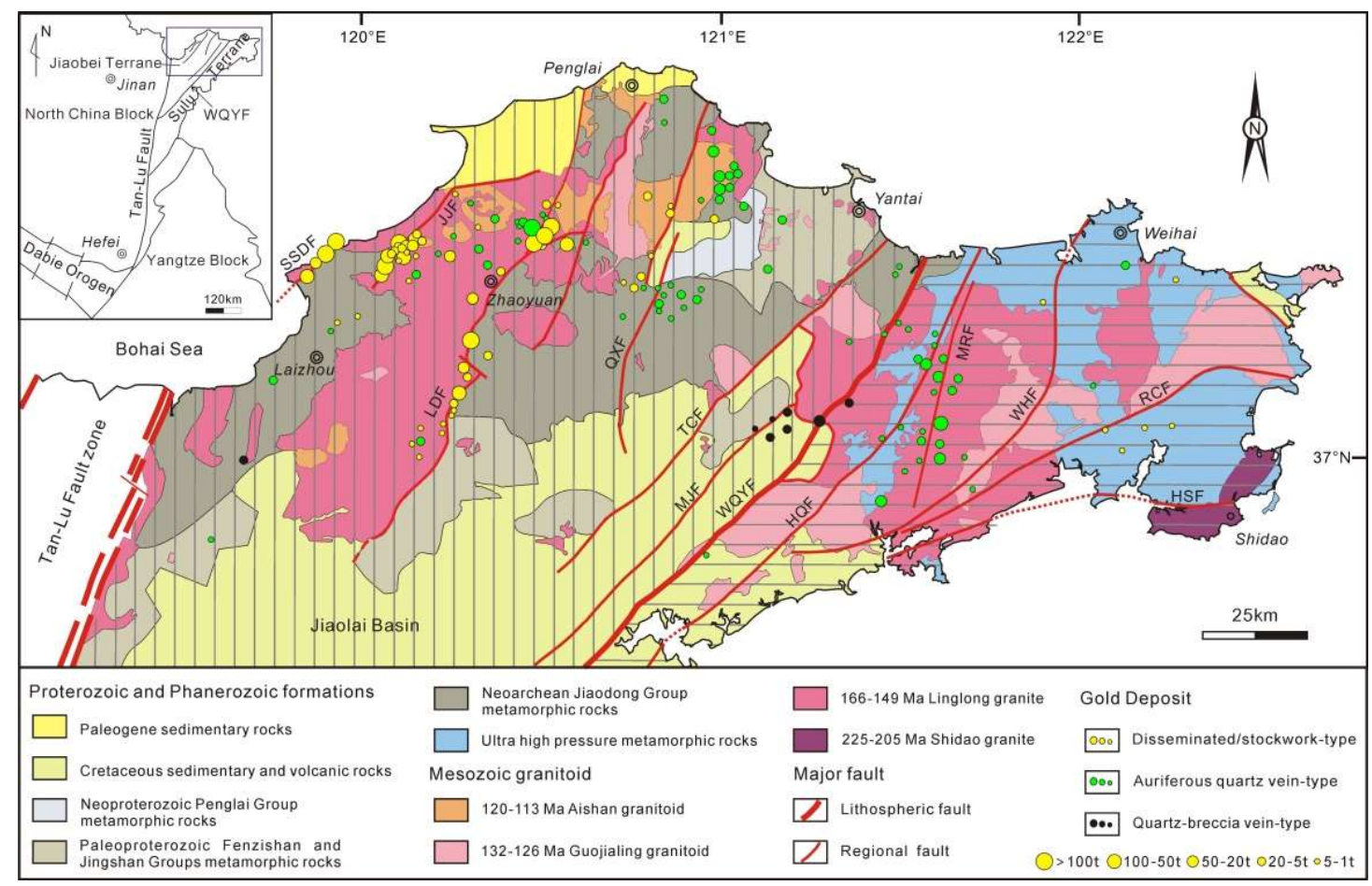

Figure 1. Simplified geological map of the Jiaodong gold province [13]. SSDF-Sanshandao fault; JJF-Jiaojia fault; LDF-Zhaoping fault; QXF-Qixia fault; TCF-Taocun fault; MJF-Muping-Jimo fault; WQYF-Wulian-Qingdao-Yantai fault; HQF-Haiyang-Qingdao fault; MRF-Muping-Rushan fault; WHF-Weihai fault; RCF-Rongcheng fault; HSF-Haiyang-Shidao fault. Reproduced with permission from [13]; published by Elsevier B.V., 2017.

Many studies have focused on geological features, ore-forming age, ore fluid characteristics, origin of the ore-forming fluid and metals, and geodynamic setting [7,12-21], all of which indicate that gold deposits throughout the whole Jiaodong Peninsula formed in broadly uniform hydrothermal fluid and physicochemical conditions [12]. Despite these intensive studies, a universal answer is not yet available, and the question of source of the ore fluids and metals is still open, as well as the genesis of gold deposit [22-30]. Fan et al. [17] concluded that the ore-forming fluids derived from mantle magma degassing in the shallow crust and are a combination of crustal and mantle components. Wang et al. [31] revealed the ore-fluid P-T-X (pressure-temperature-composition) conditions of most deposits are consistent with those typical of a metamorphic source. However, Yang et al. [32] and Deng et al. [33] proposed that the origin of the ore-forming fluid and materials may be associated with the Paleo-Pacific oceanic subducting slab. 
As the Jiaojia-type deposit is now considered to be the most important and typical gold resource in this area, the distinctive geological background, structural setting, and metallogenic characteristics in the Sanshandao gold deposit provide an excellent opportunity to evaluate the gold depositional processes for the disseminated style mineralization in detail. Although certain studies have been completed on the ore fluid of the Sanshandao deposit, the P-T conditions of gold deposition have not been well defined [17]. If fluid immiscibility did occur during gold precipitation at the deposits [34], then the homogenization temperature and pressure would correspond to the trapping $\mathrm{P}-\mathrm{T}$ conditions $[35,36]$ and a pressure correction is unnecessary $[37,38]$.

Fluid-inclusion data, ore petrography, and structural mapping are keys to determining ore genesis [39]. Fluid inclusions (FIs) trapped in hydrothermal minerals provide the best available method for defining the physical and chemical conditions of ore-forming fluids in fossilized hydrothermal systems [40]. Detailed FI study is essential to determine the origin and evolution of the ore-forming fluids. In this paper, based on detailed field and petrographic observations, FI analyses and isotope $(\mathrm{H}, \mathrm{O}, \mathrm{S})$ compositions of the ores, the ore fluid, and metal origin and evolution together with the genesis of gold deposits were evaluated in detail.

\section{Regional Geology}

The Jiaodong Peninsula is located in the southeastern part of the NNC, bounded by the north to northeast (N-NE)-trending Tan-Lu fault to the west and by the Su-Lu Ultra-High Pressure (UHP) metamorphic belt to the south (Figure 1). The Peninsula comprises the Jiaobei terrane in the northwest and Sulu terrane in the southeast. The two terranes were sutured together along the Wulian-Qingdao-Yantai fault during continental collision in the Triassic to Early Jurassic [26,41] (Figure 1). Almost all the largest gold deposits and more than $90 \%$ gold resources are preserved in the Jiaobei terrane.

The Jiaobei terrane is composed of the Jiaobei uplift in the north and the Jiaolai basin in the south. The former is principally defined by Precambrian basement and supracrustal rocks cut by Mesozoic intrusions. The Precambrian basement consists of the Neoarchean Jiaodong Group (amphibolite and mafic granulite sequence), Paleoproterozoic Fenzishan and Jingshan Group (schist, paragneiss, calc-silicate rocks, marble, and minor mafic granulite and amphibolite), and Neoproterozoic Penglai Group, which is dominated by marble, slate, and quartzite [1,21,42-44]. The Jiaodong Group is unconformable, overlain by the Fenzishan and Jingshan Group. The Jiaolai Basin mainly consists of Mesozoic volcanic rocks, which refer to the Qingshan Formation; these Mesozoic volcanic rocks formed at ca. 108-110 Ma [11]. The Qingshan Formation comprises two units, with the upper assemblage composed of rhyolite flows and pyroclastic rocks, underlain by the lower assemblage characterized by trachybasalt, latite, and trachyte [45].

The widespread Mesozoic granitoids in the Jiaodong province are traditionally divided into the Linglong, Guojialing, and Aishan Suites [46,47], with the gold mineralization being mainly hosted in the former two suites (Figure 1). The Linglong Suite is distributed between the Jiaojia and Zhaoping fault zones, composed of garnet granite, biotite granite, and amphibole-bearing biotite granite $[48,49]$, and considered to be generated by partial melting of remnant thickened Archaean lower crust during 165-150 Ma. The 132-123 Ma Guojialing Suite [13,50], which intruded into both the Late Jurassic granitoids and the Precambrian basement, mainly consists of porphyritic quartz monzonite, granodiorite, and monzogranite [46,51], and was likely derived from intense crust-mantle interaction [41,49]. The Guojialing Suite was cut by the later Early Cretaceous Aishan granitoids at ca. 118 to $110 \mathrm{Ma}$ [52]; the Aishan granitoids mainly include monzogranites and syenogranites of I-type affinity with local alkali-feldspar granite of A-type affinity [13]. In addition to the granitoids introduced above, many mafic to felsic dikes were emplaced at ca. 122-114 Ma in the gold district. They are represented by dolerite, lamprophyre, granodiorite, and syenite. The genesis of these rocks was probably caused by magma activity associated with the Cretaceous lithospheric thinning and asthenospheric upwelling [19,53]. 
Regional structures mainly include the EW, NNE-NE, and NW trending fault zones. The EW tectonic belt is a basement structure, maintain long-term activity since the Yanshan movement, mainly characterized by folds and ductile shear zones. The NW trending fault zones formed in the Archean era, followed by inherited activities during the Late Proterozoic era and large-scale intense activities accompanied by magmatism and volcanism in the Mesozoic era [25]. The NE-NNE trending faults are the most important ore controlling structures in Jiaodong district. There are four fault systems from west to east: SSDF (Sanshandao fault), JJF (Jiaojia fault), LDF (Zhaoping fault), and QXF (Qixia fault) (Figure 1), corresponding to four gold belts. These faults are argued to be subsidiary structures to the regional Tan-Lu fault system. Two main stages of deformation during the late Mesozoic era have been identified. The first stage is characterized by brittle-ductile shear zones with sinistral oblique reverse movements, caused by northwest-southeast oblique compression $[5,13,54]$. This was followed by development of brittle normal faults [3,55], accompanied by hydrothermal alteration and gold mineralization [47].

The Sanshandao fault zone is located at the western part of the Jiaodong gold district; the majority of the fault zone is covered by Quaternary sedimentary rock, which is locally exposed to the surface; the fault is $12 \mathrm{~km}$ long with a width of $50-200 \mathrm{~m}$. The distribution of the fault zone on the plane is S-type, and generally strikes $40^{\circ} \mathrm{NE}$ and dips $45^{\circ}-75^{\circ} \mathrm{SE}$. The fault zone mainly develops along the contact between the Linglong suite and Malianzhuang suite, with a continuous and stable main fault plane, characterized by mylonite and cataclastic rocks. More than $13 \%$ of the gold reserves (including the giant Sanshandao gold, Xinli, and Cangshang deposits) are hosted in the Sanshandao-Cangshang fault zone (Figures 1 and 2).

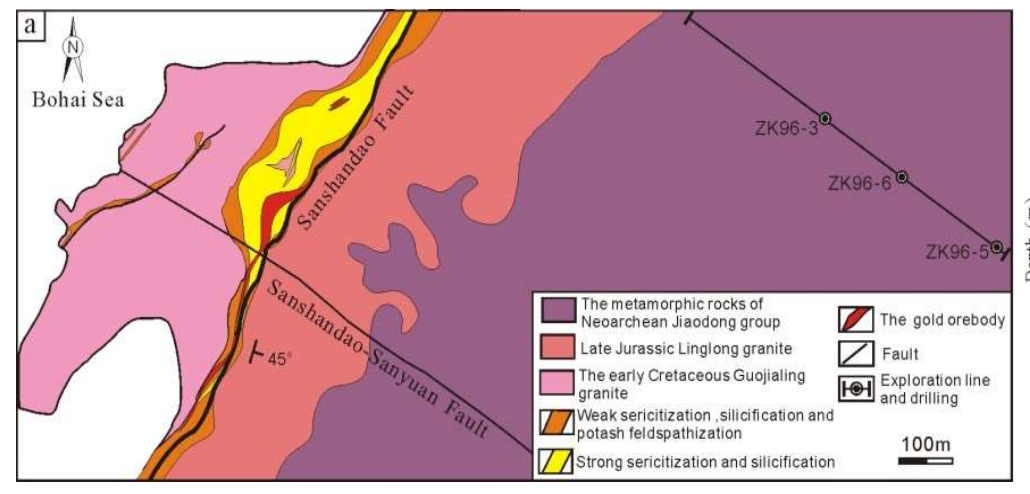

Figure 2. Simplified geological map (a) and geological cross section (b) of the Sanshandao gold deposit [21].

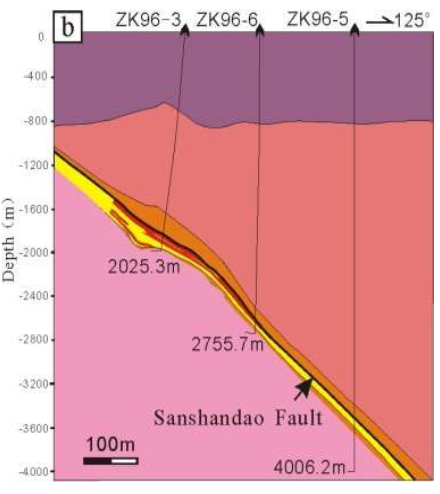

\section{Deposit Geology}

The Sanshandao gold deposit is located in the northwestern part of the Jiaobei uplift, about $25 \mathrm{~km}$ north of Laizhou City (Figure 1), with a proven gold reserve of $>200 \mathrm{t}$. A total of $80 \mathrm{t}$ gold has already been produced with an estimated annual gold production of $8 \mathrm{t}$ (Data from Shandong Gold Group Co., Ltd.). In the deposit, the Sanshandao fault follows the contact between the Linglong granite and Jiaodong group metamorphic rocks in the hanging wall, and the Guojialing Granodiorite accompanied by minor Linglong granite in the footwall (Figure 2). Linglong granite is intruded by Guojialing Granodiorite, showing a medium-grained equigranular texture, consisting mainly of Biotite, K-feldspar, plagioclase, quartz, and a small amount of magnetite and apatite. Guojialing granodiorite is characterized by a porphyritic-like texture, and the mineral assemblages are analogous to that of the Linglong granite, but with more hornblende. Dynamic recrystallized quartz occurs commonly in the Linglong and Guojialing granitoids, indicating the two suites underwent subsolid ductile deformation before mineralization.

The Sanshandao gold deposit is controlled by the Sanshandao fault. This fault generally trends northeast, dips $50^{\circ}$ southeast, and extends offshore into the Bohai Sea. The fault zone is characterized 
by fault gouge, mylonite, hydrothermal breccias, and cataclastic rocks, which comprise zones up to tens of meters thick of K-feldspar, quartz, and sericite, with both disseminated pyrite and pyrite-quartz stockworks [11], reflecting early shearing and late brittle fracturing of the structures along the fault zone, dominated by brittle failure. Two mineralization styles were identified at the gold deposit and all hosted in the footwall of the fault zone: Disseminated- and stockwork-style (Figure 3). The former contains disseminated gold within the granodiorite with strong hydrothermal alteration, including sericitization, silicification, sulfidation, and K-feldspar wall-rock halos; the degree of alteration and fracturing decrease with distance from the fault. This is the most common style mineralization in this deposit. The less common style is the gold-quartz vein/veinlet stockworks mainly controlled by the subsidiary fault.
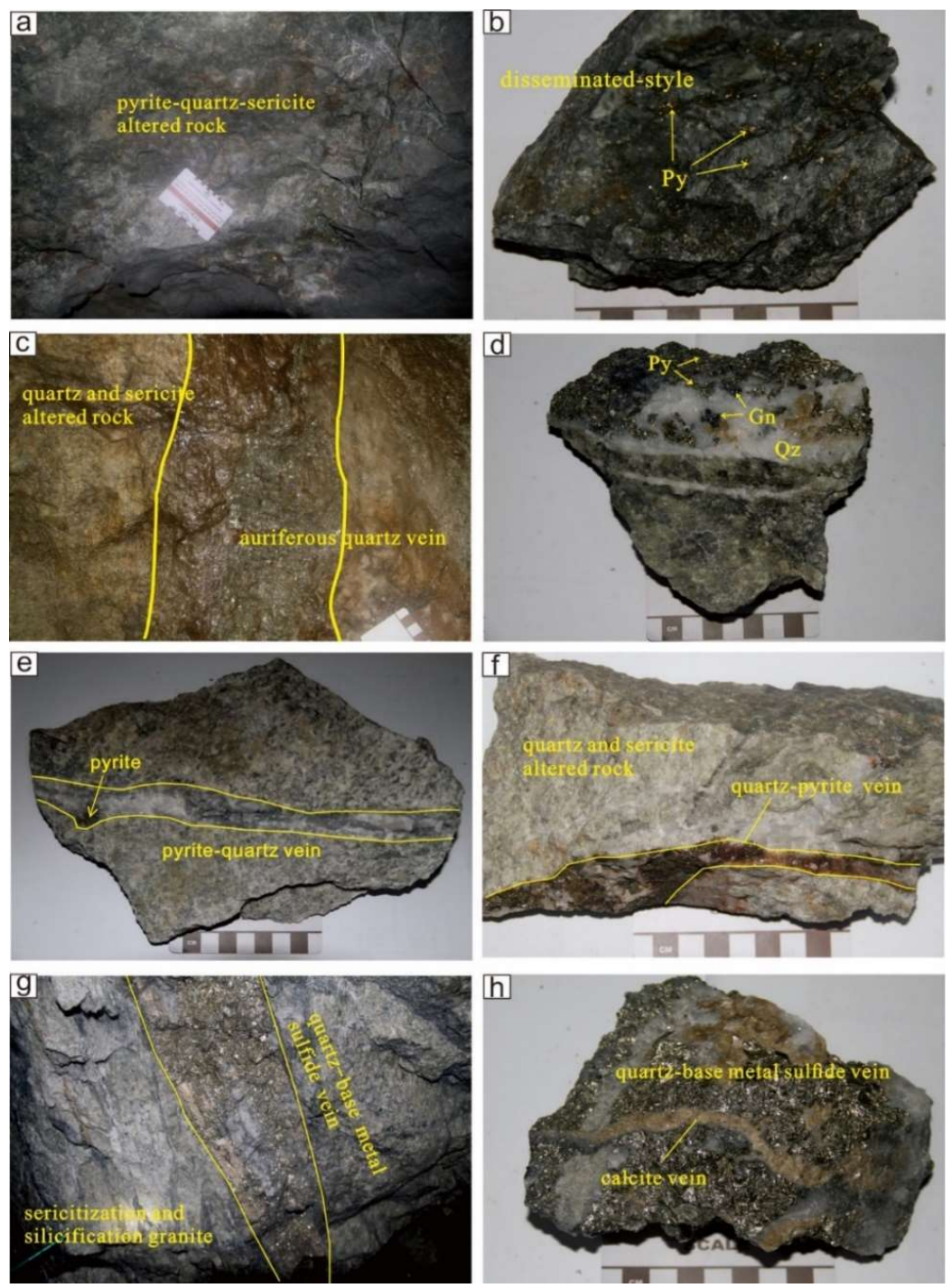

Figure 3. Field photographs demonstrating major geologic bodies with cross-cutting relationships and different mineral assemblages. (a,b) Disseminated-style ore of stage 1 (early stage); (c) auriferous quartz vein of stage 2 (main stage) in sericitized and silicified granite; (d) auriferous quartz vein-style ore of stage 3 (main stage); (e) the early-stage milky white quartz vein with disseminated pyrite; (f) main stage quartz-pyrite veinlet cut across the early-stage sericite-quartz altered rock; (g) quartz-base-metal-sulfide vein; (h) late stage (stage 4) quartz-calcite veins cutting the quartz-base-metal-sulfide vein. Qz-quartz; Gn-galena; Py-pyrite. 
The combined disseminated and veinlet mineralization form tabular orebodies broadly parallel to the Sanshandao fault zone. Six orebodies have been defined in the Sanshandao gold deposit, all of which occur in the footwall of the fault zone. The orebodies generally strike NE, dip SE, with the No. 1 orebody being the largest and the No. 2 being second. The No. 1 orebody accounts for $70.35 \%$ of the known gold resources and occurs within the middle to upper part of the pyrite-sericite-quartz alteration zone. This orebody strikes $35^{\circ} \mathrm{NE}$, dips $34^{\circ}-44^{\circ} \mathrm{SE}$, extends $1020 \mathrm{~m}$ along the strike and 700-1000 $\mathrm{m}$ along the dipping direction. It ranges in thickness from 0.95 to $12.08 \mathrm{~m}$ (average $6.65 \mathrm{~m}$ ) and extends downdip from the $-10 \mathrm{~m}$ level to below the $-1050 \mathrm{~m}$ level, with gold grade ranging from 1.74 to $15.4 \mathrm{~g} / \mathrm{t}$ (average $3.25 \mathrm{~g} / \mathrm{t}$ ). The No. 2 orebody underlays the No. 1 orebody, appearing as regular pulse, stratiform-like lenses, with a strike of $3^{\circ}-40^{\circ}$ and a dip of $32^{\circ}-44^{\circ}$. It extends $335-380 \mathrm{~m}$ in length with an average thickness of $5.74 \mathrm{~m}$. The gold grade varies from 1.55 to $24.8 \mathrm{~g} / \mathrm{t}$ (average of $3.13 \mathrm{~g} / \mathrm{t})$.

The paragenetic assemblages of the disseminated- and stockwork-veinlet-style ores are shown in Figures 3 and 4. The ore minerals mainly include pyrite, chalcopyrite, galena, sphalerite, and arsenopyrite, with minor electrum. The gangue minerals are dominated by quartz, sericite, and calcite. Combining mineral assemblages and textural characteristics with crosscutting relationships (Figure 3), four mineralization stages have been identified in this deposit: Pyrite-quartz-sericite (stage 1/early stage), quartz-pyrite-arsenopyrite (stage $2 /$ main stage), quartz-base metal-sulfide (stage 3/main stage), and quartz-carbonate (stage 4/late stage). Stage 1 is characterized by sericite-quartz-altered rocks or locally pyrite-quartz veins (Figure $3 a, b, e)$. The mineral assemblages mainly consist of milky white subhedral quartz, sericite, and minor coarse-grained, irregular, or euhedral pyrite (Figure $4 a-c)$. Little gold precipitated in this stage. Stage 2 is characterized by quartz-sulfide veins and stockworks and disseminated sulfides occurring in the sericite-quartz-altered rocks (Figure 4d), or as auriferous quartz-pyrite veins controlled by secondary structures (Figure 3c). The minerals are dominated by pyrite and white-gray quartz with a small amount of chalcopyrite, native gold, and pyrrhotite (Figure $4 \mathrm{~h}, \mathrm{i}$ ). The gold minerals primarily occur as native gold wrapped in pyrite (Figure 4i) or fill within in the gaps and/or cracks of pyrite. Stage 3 is characterized by the assemblage of gold, quartz, base metal sulfide (Figure 3d,g). Large amounts of sulfide minerals precipitated during this stage, including pyrite, galena, sphalerite, and chalcopyrite (Figure 4e,g). These base metal sulfides minerals are fine-grained, occur as veinlets or disseminated aggregates, cutting the early-stage quartz-pyrite veins and veinlets. Gold minerals are mainly native gold, filling the open fractures in pyrite and/or galena. Stage 4 is characterized by quartz-calcite veinlets, commonly marking the termination of gold mineralization. Quartz and carbonates form veins and veinlets cutting the early quartz-pyrite veinlets (Figures $3 \mathrm{~h}$ and $4 \mathrm{f}$ ) or quartz-base-metal sulfide veins in the disseminated ores or subsidiary faults. 

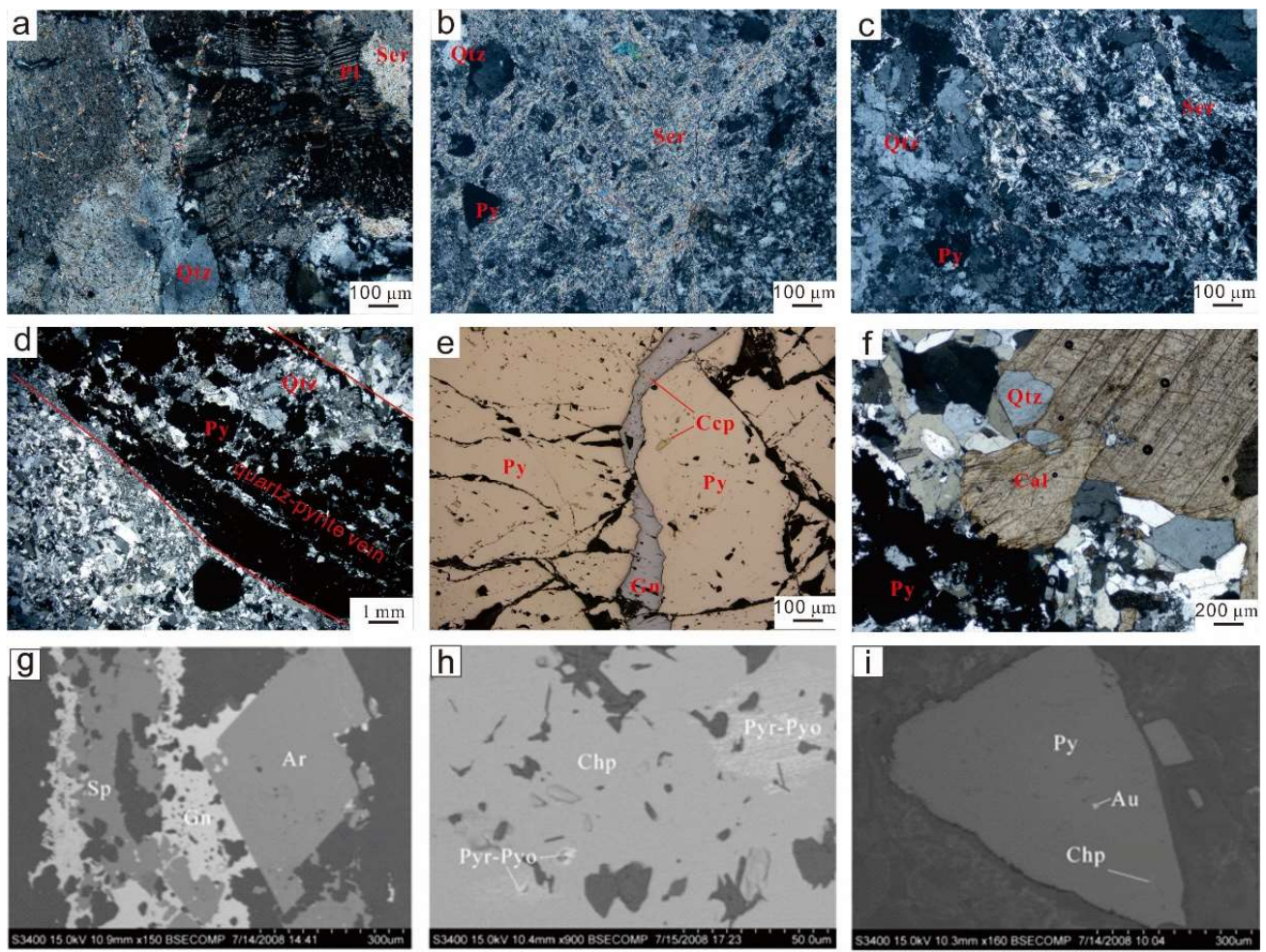

Figure 4. Photomicrographs under (a-d,f) transmitted light, (e) reflected light and ( $\mathbf{g}-\mathbf{i})$ backscattered electron images, showing important ore minerals and alteration assemblages at the Sanshandao gold deposit. (a-c) Typical sericitization alteration consisting of sericite and quartz, with minor pyrite (stage 1); (d) quartz-pyrite vein (stage 2) occurring in sericite-quartz altered rock; (e) galena cemented with chalcopyrite replacing the pyrite grain (stage 3); (f) calcite (stage 4) cutting the quartz-pyrite vein (stage 2); (g,h) typical quartz-pyrite-base-metal-sulfide ore minerals consisting of pyrite, chalcopyrite, sphalerite, and galena; (i) native gold inclusion in pyrite. Cc—calcite; Ccp-chalcopyrite; Gn—galena; Py—pyrite; Qtz—quartz; Ser—sericite; Sp—sphalerite.

\section{Sampling and Analytical Methods}

Samples for fluid-inclusion analysis were selected from $-150,-195,-255,-285,-330,-375$, $-390,-495,-510$, and $-600 \mathrm{~m}$ levels in the Sanshandao deposit, areas represented by quartz, quartz-pyrite, quartz-base-metal-sulfides, quartz-carbonate veins, and quartz-sericite-pyrite altered rocks. More than 100 doubly polished sections (about $0.2 \mathrm{~mm}$ thick) were petrographically examined in detail. Finally, 12 samples (Table 1) were selected for microthermometric and laser Raman spectroscopic investigations.

Table 1. Samples for microthermometry in the Sanshandao gold deposit.

\begin{tabular}{cccccc}
\hline Sample ID & Depth $(\mathbf{m})$ & Mineral & Sample & Depth (m) & Mineral \\
\hline SSD600C & -600 & Quartz & SSD28505 & -285 & Quartz \\
SSD51001 & -510 & Quartz & SSD25508 & -255 & Quartz \\
SSD49501 & -495 & Quartz & SSD25505 & -255 & Quartz \\
SSD39006 & -390 & Quartz & SSD19504 & -195 & Quartz \\
SSD37501 & -375 & Quartz & SSD15003 & -150 & Quartz \\
SSD33004 & -330 & Quartz & SSD-02 & 0 & Quartz \\
\hline
\end{tabular}

\subsection{Fluid-Inclusion Analysis}

Reconnaissance fluid-inclusion petrography was conducted on quartz veins from all paragenetic stages, recognized by observing intersection and overprinting relationships between different veins 
(veinlets) and alteration types (halos), and temporal-spatial relationships of gangue and ore minerals using a microscope. Subsequently, optical microscopy and detailed fluid-inclusion petrography were performed on selected quartz vein samples with a microscope using a series of doubly polished sections. Accuracy of the microthermometric data on selected fluid inclusions was ensured by calibration against the triple-point of pure $\mathrm{CO}_{2}\left(-56.6^{\circ} \mathrm{C}\right)$, the freezing point of water $\left(0.0^{\circ} \mathrm{C}\right)$ and the critical point of water $\left(374.1^{\circ} \mathrm{C}\right)$ using synthetic fluid inclusions supplied by FLUID INC (an incorporation in USA).

The microthermometric analysis of fluid inclusions was performed using a LinkamTHMSG 600 (Linkam Scientific Instruments Company, Surrey, UK) heating-cooling stage (from -198 to $600{ }^{\circ} \mathrm{C}$ ) on a Leitz microscope (Wetzlar, Germany) at the Fluid Inclusion Laboratories, State Key Laboratory of Geological Processes and Mineral Resources, China University of Geosciences, Beijing, China. Synthetic fluid inclusions were used to calibrate the stage to ensure the precision of analysis. Measurements of the melting temperatures of the carbonic phase $\left(\mathrm{Tm}_{\mathrm{CO} 2}\right)$, ice final melting temperatures $\left(\mathrm{Tm}_{\mathrm{ice}}\right)$ and clathrate melting temperatures of $\mathrm{CO}_{2}\left(\mathrm{Tm}_{\text {clath }}\right)$ were recorded at the heating rate of $0.1-0.2{ }^{\circ} \mathrm{C} / \mathrm{min}$. For the total homogenization and the $\mathrm{CO}_{2}$ homogenization temperatures $\left(\mathrm{Th}_{\mathrm{CO} 2}\right)$, the heating rate was $0.2-0.4^{\circ} \mathrm{C} / \mathrm{min}$. Salinities were then calculated using $\mathrm{Tm}_{\text {ice }}[35,40]$ and $\mathrm{Tm}_{\text {clath }}[56]$. The $\mathrm{CO}_{2}$ densities can be well defined through $\mathrm{Th}_{\mathrm{CO} 2}$. Bulk composition and density were determined using the program of Bakker et al. [57] and software of Brown et al. [58].

\subsection{Laser Raman Spectroscopy}

Laser Raman spectroscopic analysis was carried out at the Institute of Geology and Geophysics of the Chinese Academy of Sciences (IGGCAS) by using Raman 2000 laser Raman spectrometer (British Ranishaw, London, UK). The wavelength was $514.5 \mathrm{~nm}$ for the Ar ion laser. The spectrum ranged from 50 to $9000 \mathrm{~cm}^{-1}$, with a reproducibility of $\pm 0.2 \mathrm{~cm}^{-1}$ and a resolution of $2 \mathrm{~cm}^{-1}$. The spatial resolution was better than $4 \mu \mathrm{m}$ longitudinally and lower than $1 \mu \mathrm{m}$ in the transverse direction.

\subsection{Isotope Analysis}

Isotopes of hydrogen, oxygen, and sulfur were analyzed at the Stable Isotope Laboratory, National Key Laboratory for Tectonic Evolution of Lithosphere, Institute of Geology and Geophysics, Chinese Academy of Sciences (IGGCAS, Beijing, China). Samples from different ore-forming stages were crushed to 40-60 mesh to separate the mineral grains. The quartz, calcite, and pyrite grains for isotopic analysis were handpicked under a binocular microscope to achieve $99 \%$ purity.

For hydrogen isotopic measurement, the water from secondary fluid inclusions were gradually removed in a vacuum system after drying the selected single mineral below $105{ }^{\circ} \mathrm{C}$, then heating to $600{ }^{\circ} \mathrm{C}$ to cause the remaining inclusions to burst. The released water was disposed by collection, condensation, and purification, and replaced by zinc to obtain the hydrogen for mass spectrometry analysis [59]. Oxygen isotope analyses of quartz were conducted on the same samples for hydrogen isotopes using the following procedure. First, quartz grains were reacted with $\mathrm{BrF}_{5}$ for 15 hours at $500-550{ }^{\circ} \mathrm{C}$ to produce oxygen. Then, the generating $\mathrm{O}_{2}$ was purified using liquid nitrogen and converted to $\mathrm{CO}_{2}$ on a platinum-coated carbon rod at $700{ }^{\circ} \mathrm{C}$ for mass spectrometry analysis. Both oxygen and hydrogen determinations were made on a MAT-252 (Finnigan company, San Francisco, CA, USA) mass spectrometer. The H-O isotope analysis results adopted the Vienna Standard Mean Ocean Water (V-SMOW), with a precision of $\pm 1 \%$ for $\delta \mathrm{D}$, and $\pm 0.2 \%$ for $\delta^{18} \mathrm{O}$ [59].

For sulfur isotope analyses, 36 pyrite samples from ores of the Sanshandao deposit were used. $\mathrm{SO}_{2}$ was generated through the reaction of pyrite and cuprous oxide under a vacuum pressure of $2 \times 10^{-2} \mathrm{~Pa}$ at $980^{\circ} \mathrm{C}$ and was measured using a Delta-S (Finnigan company, San Francisco, CA, USA) mass spectrometer for sulfur isotope analysis. All the sulfur isotopic compositions are reported relative to CDT (Cañon Diablo Troilite). S isotope analysis results adopted Vienna Cañon Diablo Troilite (V-CDT) standards, with a precision of $\pm 0.2 \%$ [59]. 


\section{Results}

\subsection{Fluid-Inclusion Types}

Three types of fluid inclusion were identified in this study based on microthermometry and Raman spectroscopy: Pure $\mathrm{CO}_{2}$ gas (type I), $\mathrm{CO}_{2}-\mathrm{H}_{2} \mathrm{O}$ inclusions (type II), and aqueous inclusions (type III). Type I inclusions are completely filled with gas, darkened or even black, and are only light at the center of the bubble. Their size ranges from 5 to $10 \mu \mathrm{m}$. We observed that they coexist with the type II inclusions in the early stage and with type II and type III inclusions in the main stage (Figure 5g). These inclusions appear alone or scattered and are interpreted to be primary inclusions.
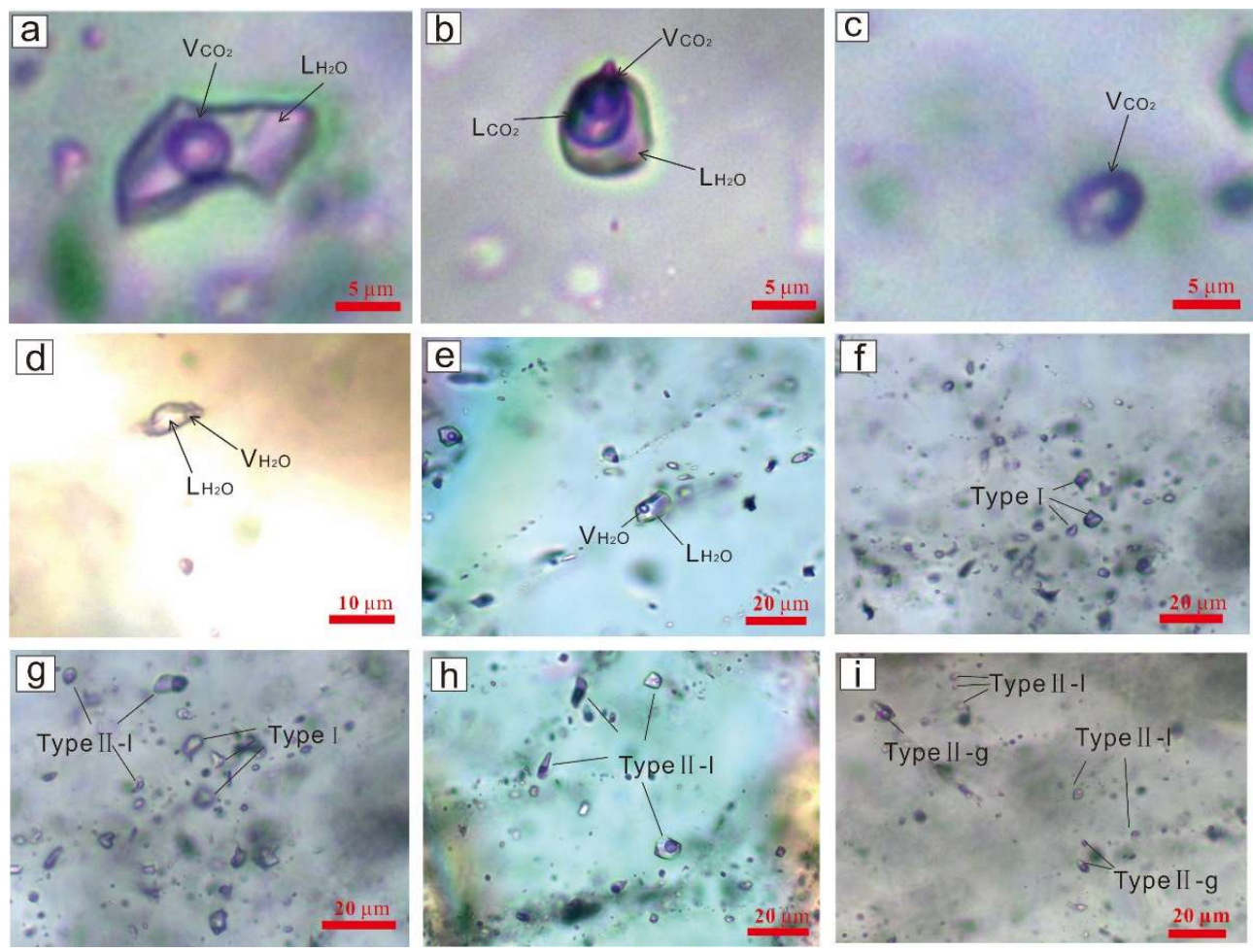

Figure 5. Photomicrographs of typical fluid inclusions in the Sanshandao gold deposit. (a) Type II inclusion consisting of two $\left(\mathrm{H}_{2} \mathrm{O}\right.$ liquid $+\mathrm{CO}_{2}$ vapor/liquid) phases; (b) type II inclusion consisting of three $\left(\mathrm{H}_{2} \mathrm{O}\right.$ liquid $+\mathrm{CO}_{2}$ liquid $+\mathrm{CO}_{2}$ vapor) phases; (c) type I inclusion consisting of pure gas $\left(\mathrm{CO}_{2}\right.$ vapor) phase; (d) type III inclusion consisting of two $\left(\mathrm{H}_{2} \mathrm{O}\right.$ liquid $+\mathrm{H}_{2} \mathrm{O}$ vapor) phases; (e) fluid-inclusion assemblage (FIA) consists of secondary type III inclusions; (f) FIA consists of type 1 inclusions; (g) FIA consists of type I and type II-l inclusions occurring together in stage 2 quartz; (h) FIA consists of type II-l inclusions; (i) FIA consists of type II-l and type II-g inclusions occurring together in stage 3 quartz.

Type II inclusions can be further divided into two subtypes, containing two-phase $\left(\mathrm{V}_{\mathrm{CO} 2}+\mathrm{L}_{\mathrm{H} 2 \mathrm{O}}\right)$ or three-phase $\left(\mathrm{V}_{\mathrm{CO} 2}+\mathrm{L}_{\mathrm{CO} 2}+\mathrm{L}_{\mathrm{H} 2 \mathrm{O}}\right)$ inclusions at room temperature with sizes from 5 to $15 \mu \mathrm{m}$ (Figure 5a). The two-phase inclusions (liquid phase and gas phase) have a boundary between the two phases denoted by a black circle. They can be subdivided into gas inclusions (II-g type) with gas filling degree greater than $50 \%(\mathrm{~V} /(\mathrm{V}+\mathrm{L})>50 \%)$ and aqueous inclusions (II-1 type) with liquid filling degree lower than $50 \%(\mathrm{~L} /(\mathrm{V}+\mathrm{L})<50 \%)$. In some samples, we found the coexistence of type II-g and II-1 inclusions, or type II and type I inclusions (Figure $5 \mathrm{~g}$,i). This reflects the fluid evolution. Components of the inclusions can be $\mathrm{H}_{2} \mathrm{O}, \mathrm{CO}_{2}$, or saline solution. The three-phase inclusions usually occur with $\mathrm{V}_{\mathrm{CO} 2}+\mathrm{L}_{\mathrm{CO} 2}$ accounts for $20 \%-40 \%$ of the total volume (Figure $5 \mathrm{~b}$ ).

Type III inclusions consist of two phases $\left(\mathrm{H}_{2} \mathrm{O}\right.$ liquid and $\mathrm{H}_{2} \mathrm{O}$ vapor) and are mostly colorless (Figure $5 \mathrm{~d}, \mathrm{e}$ ); they commonly occur between 5 and $10 \mu \mathrm{m}$, with the vapor occupying $5 \%-30 \%$ of the 
total cavity volume. These fluid inclusions have irregular or regular shapes and develop especially in late-stage quartz. The secondary type III inclusions are generally cut across the crystal boundaries of quartz with the primary ones occur as isolated singles or group.

The primary fluid inclusions are identified according to (1) the shape of the fluid inclusions. The shape of primary inclusions is usually regular and scattered, the secondary inclusions are usually irregular in shape, distributed along healing fissures, and sometimes healing fissures pass through different minerals; (2) the density, homogenization temperature, salinity, and composition of inclusions of the same origin are the same or similar, so the inclusions can be compared and classified with known primary and secondary inclusions. (3) In gold-bearing quartz veins, gold coexists with pyrite, whereas quartz in pyrite coexists with natural gold and pyrite, so fluid inclusions in quartz can represent the ore-forming fluids.

\subsection{Microthermometry}

The early-stage quartz grains mainly include the type II inclusions. The carbonic phase melting temperatures $\left(\mathrm{Tm}_{\mathrm{CO} 2}\right)$ range from -56.9 to $-56.4{ }^{\circ} \mathrm{C}$ (Table 2, Figure 6), close to the triple point of pure $\mathrm{CO}_{2}\left(-56.6^{\circ} \mathrm{C}\right)$, indicating that the gas phase mainly comprises $\mathrm{CO}_{2}$ with few other volatiles. The $\mathrm{CO}_{2}$ clathrate melting temperature is between $7.4^{\circ} \mathrm{C}$ and $7.7^{\circ} \mathrm{C}$, corresponding to salinities of $0.35 \mathrm{wt} \%-10.4 \mathrm{wt} \% \mathrm{NaCl}$ equivalent. The carbonic phases $\left(\mathrm{Th}_{\mathrm{CO} 2}\right)$ partially homogenize to liquid at temperatures from 27.4 to $31.2{ }^{\circ} \mathrm{C}$. Total homogenization $\left(\mathrm{Th}_{\mathrm{TOT}}\right)$ into liquid of the carbonic and aqueous occurs between 280 and $400{ }^{\circ} \mathrm{C}$, corresponding to densities of $0.61-1.07 \mathrm{~g} / \mathrm{cm}^{3}$, (Table 1 , Figure 6).
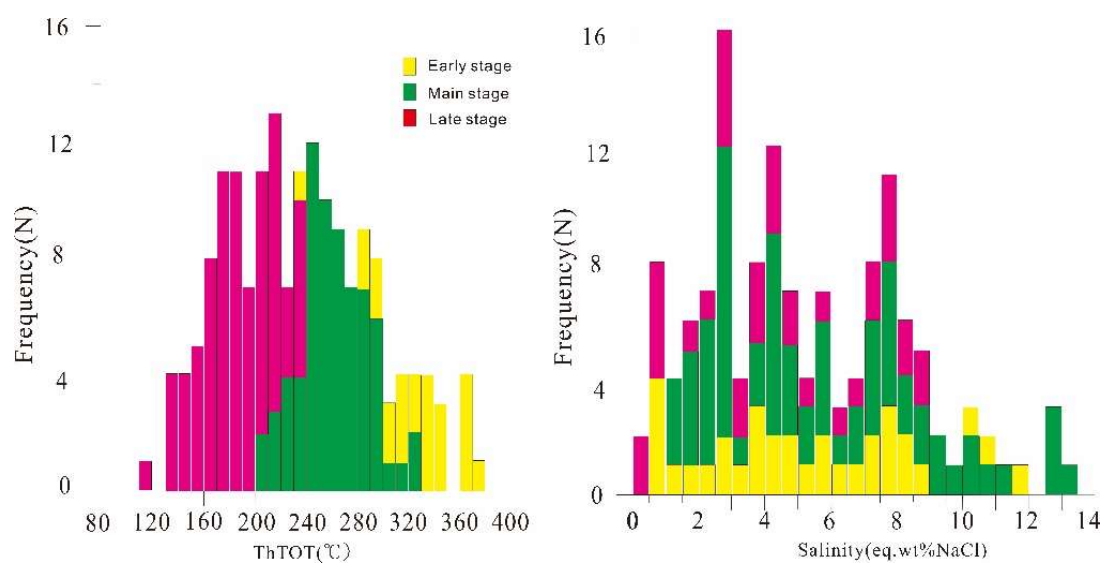

Figure 6. Histograms of microthermometric data showing temperatures of (a) $\mathrm{Th}_{\mathrm{TOT}}$ and (b) salinity.

Quartz grains of the main stage include all three type FIs and are dominated by type II and type III. Melting temperatures of the carbonic phase $\left(\mathrm{Tm}_{\mathrm{CO} 2}\right)$ of type II inclusions occur between -59.3 and $-57.6^{\circ} \mathrm{C}$, commonly below the pure $\mathrm{CO}_{2}$ melting point $\left(-56.6{ }^{\circ} \mathrm{C}\right)$, demonstrating that the existence of other gas components, such as $\mathrm{CH}_{4}$ and $\mathrm{N}_{2}$ [60], Melting temperatures of the $\mathrm{CO}_{2}$ clathrate $\left(\mathrm{Tm}_{\text {clath }}\right)$ occur between $7.3^{\circ} \mathrm{C}$ and $8.0^{\circ} \mathrm{C}$, corresponding to the fluid salinities from $2.2 \mathrm{wt} \%$ to $13.33 \mathrm{wt} \% \mathrm{NaCl}$ equivalent. The total $\left(\mathrm{Th}_{\mathrm{TOT}}\right)$ and carbonic phases $\left(\mathrm{Th}_{\mathrm{CO} 2}\right)$ homogenization into liquid range between 220 and $320^{\circ} \mathrm{C}$ and 22 and $31.2{ }^{\circ} \mathrm{C}$, respectively. The final ice melting temperature ( $\left.\mathrm{Tm}_{\text {ice }}\right)$ of type III is between -6.0 and $-4.0^{\circ} \mathrm{C}$.

In the late stage, type I FIs were generally observed in the quartz-calcite veins. The $\mathrm{Tm}_{\mathrm{CO} 2}$ occurs between -56.8 and $-56.6{ }^{\circ} \mathrm{C}$, showing the gas components are almost pure $\mathrm{CO}_{2}$. The $\mathrm{Tm}_{\text {clath }}$ ranges from 6.4 to $8.2{ }^{\circ} \mathrm{C}$ and $\mathrm{Tm}_{\text {ice }}$ is between -3.5 and $-0.0^{\circ} \mathrm{C}$, yielding salinities of $0.1 \mathrm{wt} \%-12.5 \mathrm{wt} \% \mathrm{NaCl}$ equivalent. Final homogenization into liquid of these inclusions is between 150 and $230{ }^{\circ} \mathrm{C}$ (Table 1 , Figure 6), yielding densities of $0.82-1 \mathrm{~g} / \mathrm{cm}^{3}$. 
Table 2. Summary of the microthermometric data for fluid inclusions trapped in quartz and calcite from the Sanshandao gold deposit.

\begin{tabular}{|c|c|c|c|c|c|c|c|c|c|c|}
\hline Stage & Sample & Type & $\operatorname{Tm}_{\mathrm{CO} 2}\left({ }^{\circ} \mathrm{C}\right)$ & $\mathrm{Tm}_{\text {clath }}\left({ }^{\circ} \mathrm{C}\right)$ & $\mathrm{Tm}_{\text {ice }}\left({ }^{\circ} \mathrm{C}\right)$ & $\mathrm{Th}_{\mathrm{CO} 2}\left({ }^{\circ} \mathrm{C}\right)$ & $\mathrm{Th}_{\text {tot }}\left({ }^{\circ} \mathrm{C}\right)$ & $\begin{array}{c}\text { Salinity (wt \% } \\
\mathrm{NaCl} \text { eqv.) }\end{array}$ & $\begin{array}{c}\text { Bulk Density } \\
\left(\mathrm{g} / \mathrm{cm}^{3}\right)\end{array}$ & $\begin{array}{c}\mathrm{CO}_{2} \text { Density } \\
\left(\mathrm{g} / \mathrm{cm}^{3}\right)\end{array}$ \\
\hline early & $\begin{array}{l}\text { SSD28505 } \\
\text { SSD-02 } \\
\text { SSD33004 } \\
\text { SSD19504 }\end{array}$ & $\begin{array}{l}\text { II } \\
\text { II } \\
\text { II } \\
\text { II }\end{array}$ & $\begin{array}{l}\text { from }-56.9 \text { to } \\
-56.4(n=19)\end{array}$ & $\begin{array}{l}7.4-7.7 \\
(n=23)\end{array}$ & & $\begin{array}{c}27.4-31.2 \\
(n=9)\end{array}$ & $\begin{array}{l}280-400 \\
(n=22)\end{array}$ & $\begin{array}{c}0.35-10.4 \\
(n=23)\end{array}$ & $\begin{array}{c}0.61-1.07 \\
(n=12)\end{array}$ & $\begin{array}{c}0.52-0.93 \\
(n=6)\end{array}$ \\
\hline main & $\begin{array}{l}\text { SSD51001 } \\
\text { SSD49501 } \\
\text { SSD39006 } \\
\text { SSD25505 }\end{array}$ & $\begin{array}{c}\text { III } \\
\text { II } \\
\text { II } \\
\text { I }\end{array}$ & $\begin{array}{c}\text { from }-59.3 \text { to } \\
-56.6(n=25) \\
\text { from }-57.6 \text { to } \\
-56.4(n=9)\end{array}$ & $\begin{array}{l}7.3-8.0 \\
(n=31)\end{array}$ & $\begin{array}{c}\text { form }-7.5 \text { to } \\
-3.5(n=13)\end{array}$ & $\begin{array}{c}22-31.2 \\
(n=11) \\
24.3-28.4 \\
(n=8)\end{array}$ & $\begin{array}{l}210-300 \\
(n=28) \\
220-320 \\
(n=32)\end{array}$ & $\begin{array}{c}5.7-11.1 \\
(n=13) \\
2.2-13.33 \\
(n=31)\end{array}$ & $\begin{array}{c}0.77-0.94 \\
(n=22) \\
0.7-0.98 \\
(n=25)\end{array}$ & $\begin{array}{c}0.64-0.90 \\
(n=6) \\
0.52-0.84 \\
(n=4)\end{array}$ \\
\hline late & $\begin{array}{l}\text { SSD15003 } \\
\text { SSD25508 } \\
\text { SSD600C }\end{array}$ & $\begin{array}{l}\text { III } \\
\text { III } \\
\text { III }\end{array}$ & & & $\begin{array}{c}\text { from }-3.5 \text { to } \\
0.0(n=33)\end{array}$ & & $\begin{array}{l}100-230 \\
(n=68)\end{array}$ & $\begin{array}{l}0.1-8.5 \\
(n=26)\end{array}$ & $\begin{array}{c}0.82-1 \\
(n=27)\end{array}$ & \\
\hline
\end{tabular}




\subsection{Fluid-Inclusion Composition}

Laser Raman spectroscopy indicated that the volatiles of the early mineralization stage are characterized by $\mathrm{CO}_{2}$ and $\mathrm{H}_{2} \mathrm{O}$; no $\mathrm{CH}_{4}$ or $\mathrm{N}_{2}$ were detected (Figure $7 \mathrm{~b}, \mathrm{~d}$ ). However, in the main stage, abundant $\mathrm{CH}_{4}$ was detected in many of the type II fluid inclusions (Figure 7a,c), but no $\mathrm{H}_{2} \mathrm{~S}$ or $\mathrm{N}_{2}$ were detected. This is consistent with the microthermometric results that showed that melting temperatures of the carbonic phase are near $-56.6{ }^{\circ} \mathrm{C}$ in early-stage mineralization and below $-56.6{ }^{\circ} \mathrm{C}$ in main stage mineralization. For the type III FIs in the middle- and late-stage quartz, the component is composed of $100 \%$ liquid $\mathrm{H}_{2} \mathrm{O}$.
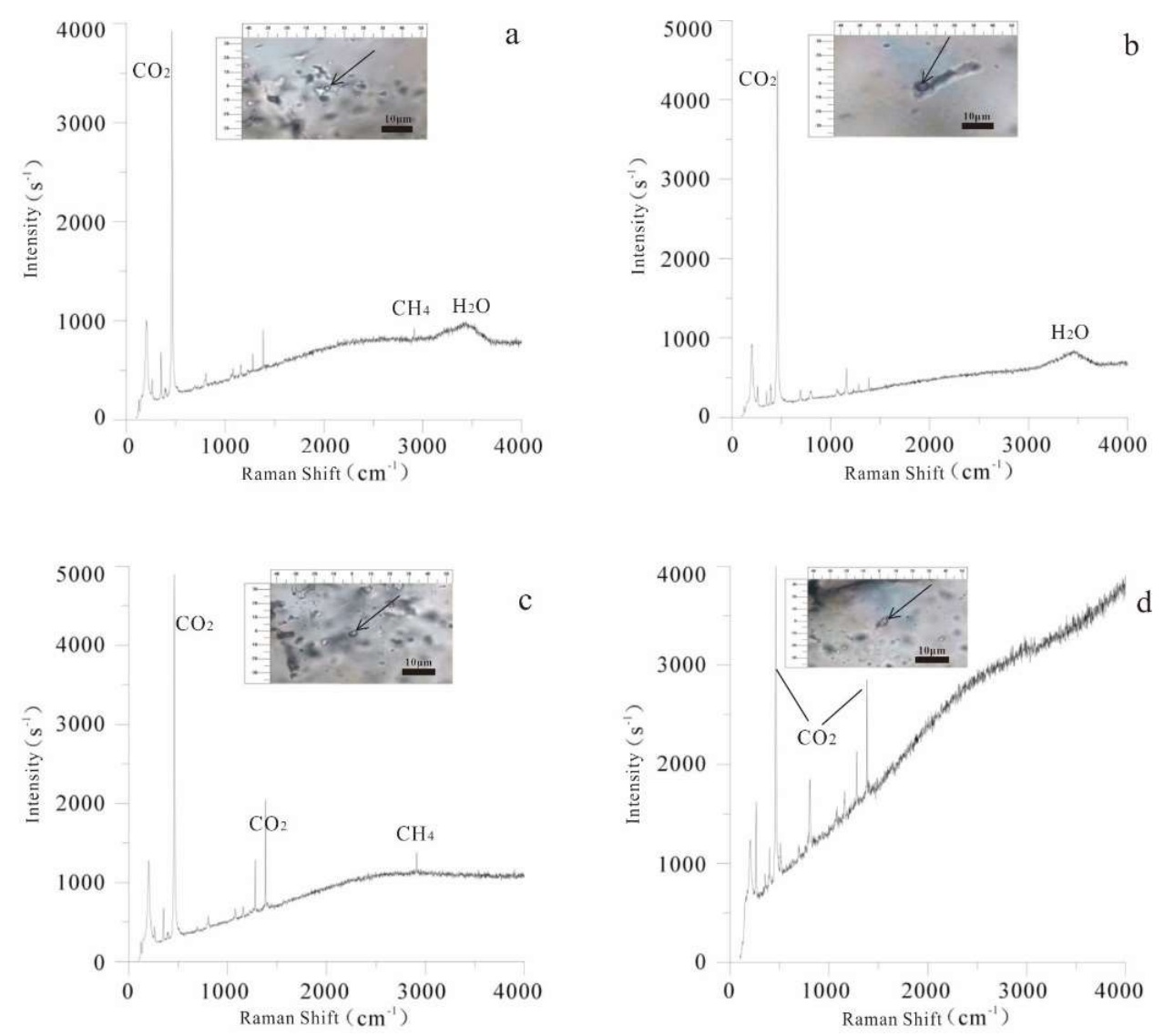

Figure 7. Representative Raman spectra of fluid inclusions in quartz. (a) Two-phase type II fluid inclusion, showing a small amount of $\mathrm{CH}_{4}$; (b) three-phase type II fluid inclusion, containing water only; (c) two-phase type II fluid inclusion, showing much more $\mathrm{CH}_{4}$; and (d) one-phase type I fluid inclusion.

\subsection{Isotope Composition}

The hydrogen and oxygen isotopic data obtained from this and previous studies in the Sanshandao deposit are listed in Table 3 . The $\delta \mathrm{D}_{\mathrm{V}-\mathrm{SMOW}}$ values for fluid inclusions in quartz range from $-62 \%$ to $-100 \%$, with a median value of $-86 \%$. The $\delta \mathrm{D}_{\mathrm{V}-\mathrm{SMOW}}$ values of fluid inclusions in the early stage are between $-86 \%$ and $-100 \%$, main stage from $-62 \%$ to $-95 \%$ (median $-84 \% 0$ ), and late stage from $-70 \%$ to $-99 \%$. The $\delta \mathrm{D}_{\mathrm{V}-\mathrm{SMOW}}$ for the sericite ranges from -48 to $-67 \%$ in the main stage, with a median value of $-53 \%$. The $\delta^{18} \mathrm{O}$ values of hydrothermal quartz $\left(\delta^{18} \mathrm{O}_{\mathrm{SMOW}}, \%\right.$; quartz) occur between $9.7 \%$ and $15.1 \%$ (mainly $10.7 \% 0-12.5 \%$ ) with a median of $12.4 \%$ (Table 3). Oxygen isotopic compositions of hydrothermal water in equilibrium with quartz were calculated based on an extrapolation of the fractionation formula: $1000 \ln \alpha=\delta^{18} \mathrm{O}_{\text {quartz }}-\delta^{18} \mathrm{O}_{\mathrm{H} 2 \mathrm{O}}=3.38 \times 10^{6} / \mathrm{T}^{2}-3.40$ [61]. The fractionation factors were calculated using the mean value of the homogenization temperatures of fluid inclusions

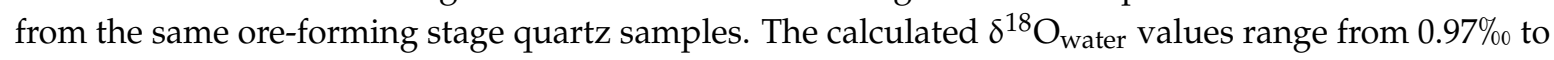


$10.79 \%$ with a median value of 5.5\% . The calculated $\delta^{18} \mathrm{O}_{\text {water }}$ values of the early stage are $4.9 \% 0-9.4 \% 0$ (median 7.0\%0); main stage, 4.1\%o-8.9\% (median 6.6\%); and late stage, $1.2 \% 0-2.6 \%$.

Table 3. Oxygen and hydrogen isotope analyses in the Sanshandao gold deposit.

\begin{tabular}{|c|c|c|c|c|c|c|c|c|}
\hline Stage & Sample & Mineral & $\begin{array}{c}\delta D_{\text {V-SMOW }} \\
(\%)\end{array}$ & $\delta D_{\text {water }}$ & $\begin{array}{l}\mathcal{\delta}^{18} \mathrm{O}_{\text {mineral }} \\
(\% 0)_{\text {SMOW }}\end{array}$ & $\begin{array}{l}\delta^{18} \mathrm{O}_{\text {water }} \\
(\% 0) \text { sMOW }\end{array}$ & $\mathrm{T}\left({ }^{\circ} \mathrm{C}\right)$ & Reference \\
\hline \multirow{5}{*}{ early } & SSD28505 & quartz & -100 & & 13.3 & 4.9 & 315 & $\begin{array}{l}\text { This } \\
\text { study }\end{array}$ \\
\hline & \multirow[t]{4}{*}{ SSD02 } & quartz & -86 & & 13.5 & 9.4 & 350 & $\begin{array}{l}\text { This } \\
\text { study }\end{array}$ \\
\hline & & quartz & & & 14.0 & 7.1 & 320 & \multirow{3}{*}{ [62] } \\
\hline & & quartz & & & 15.0 & 7.0 & 290 & \\
\hline & & quartz & & & 18.8 & 7.5 & 220 & \\
\hline \multirow{16}{*}{ main } & & sericite & -52 & -36 & 10.7 & 7.6 & 250 & \multirow{6}{*}{ [35] } \\
\hline & & sericite & -48 & -32 & 11.7 & 8.6 & 250 & \\
\hline & & sericite & -52 & -36 & 12.0 & 8.9 & 250 & \\
\hline & & sericite & -53 & -37 & 9.7 & 6.6 & 250 & \\
\hline & & sericite & -50 & -33 & 10.9 & 7.8 & 250 & \\
\hline & & sericite & -67 & -51 & 11.0 & 7.9 & 250 & \\
\hline & & quartz & -92 & & 12.5 & 4.1 & 280 & \multirow{2}{*}[62]{} \\
\hline & & quartz & -72 & & 12.8 & 4.8 & 290 & \\
\hline & & quartz & -62 & & 14.3 & 6.9 & 300 & \multirow[b]{2}{*}{ [63] } \\
\hline & & quartz & -71 & & 14.7 & 5.3 & 250 & \\
\hline & SSD600H & quartz & -65 & & 13.2 & 4.7 & 284 & \\
\hline & SSD51001 & quartz & -95 & & 13.6 & 5.5 & 272 & \\
\hline & SSD49501 & quartz & -86 & & 13.9 & 5.9 & 258 & This \\
\hline & SSD39006 & quartz & -85 & & 13.9 & 5.2 & 255 & study \\
\hline & SSD39007 & quartz & -84 & & 12.6 & 4.2 & 250 & \\
\hline & SSD25505 & quartz & -94 & & 12.8 & 4.4 & 247 & \\
\hline \multirow{4}{*}{ late } & & quartz & -92 & & 13.4 & 2.5 & 220 & [63] \\
\hline & & quartz & -70 & & 11.1 & 1.4 & 250 & [62] \\
\hline & SSD15003 & quartz & -76 & & 13.5 & 2.6 & 200 & This \\
\hline & SSD25508 & quartz & -99 & & 13.5 & 1.2 & 177 & study \\
\hline
\end{tabular}

The $\delta^{34} S_{\text {V-CDT }}$ values of pyrite, sphalerite, and galena were all obtained from the main stage in the Sanshandao gold deposit, listed in Table 4 and graphically shown in Figure 8 . The $\delta^{34} S_{C D T}$ values range from $7.8 \%$ to $12.6 \%$, with a median value of $11.4 \%$.

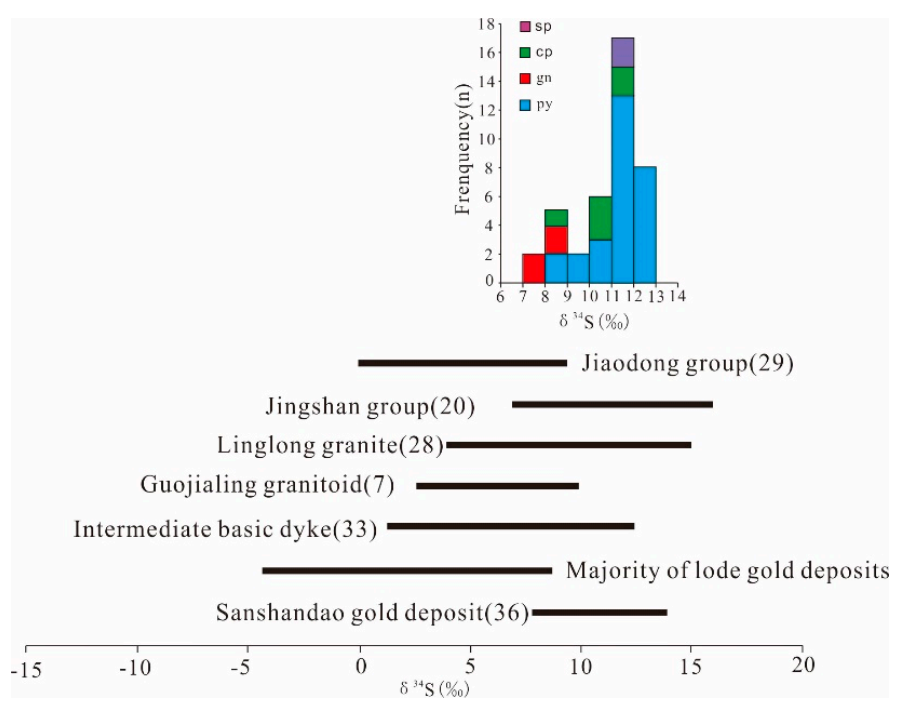

Figure 8. (a) Histograms of $\delta^{34} \mathrm{~S}$ values of sulfide minerals from the Sanshandao gold deposit; (b) comparison of sulfur isotopic compositions of main mineralization stages at Sanshandao and related major geologic bodies. The ranges of major geologic bodies were obtained from Yang et al. [12]. 
Table 4. Sulfur isotope analyses in the Sanshandao gold deposit.

\begin{tabular}{cccccc}
\hline Mineral & $\boldsymbol{\delta}^{\mathbf{3 4}} \mathbf{S}\left(\boldsymbol{\%}_{0}\right)$ & Reference & Mineral & $\boldsymbol{\delta}^{\mathbf{3}} \mathbf{S}\left(\mathbf{\%}_{0}\right)$ & Reference \\
\hline Py & 11.1 & & Gn & 7.9 & \\
Py & 9.7 & & Sp & 11.4 & \\
Py & 11.5 & & Sp & 11.1 & \\
Gn & 7.8 & This & Py & 11.8 & [64] \\
Py & 11.8 & study & Py & 11.6 & \\
Py & 11.0 & & Py & 11.1 & \\
Py & 11.0 & & Py & 10.5 & \\
Py & 10.7 & & Py & 10.4 & \\
Py & 11.8 & & Cp & 8.3 & [65] \\
Py & 12.6 & & Py & 9.5 & \\
Py & 12.6 & & Py & 12.0 & \\
Py & 12.6 & {$[63]$} & Py & 12.0 & \\
Cp & 10.1 & & Py & 11.7 & [35] \\
Cp & 10.7 & & Py & 11.9 & \\
Cp & 10.5 & & Py & 11.5 & \\
Py & 11.3 & & Py & 12.6 & \\
Cp & 11.5 & {$[64]$} & Py & 12.5 & [65] \\
Cp & 11.4 & & Py & 12.1 & \\
\hline
\end{tabular}

\section{Discussion}

\subsection{Fluid Immiscibility in the Main Stage}

As described above, the type I, II, and III FIs coexisted during the main stage at the Sanshandao gold deposit (Figure 5). These FIs are spatially associated with each other, indicating that the ore-forming fluids were in a heterogeneous thermal condition when they were trapped [31]. This phenomenon can result from one of the three possible mechanisms: (1) Fluid immiscibility by unmixing from the homogeneous fluid [32], (2) mixing of different fluids [66], and (3) necking down as the fluids were not necessarily heterogeneous during trapping [57].

Mixing of two different fluids would cause the inclusions to show a wide range of compositions and degrees of filling [66], which was not observed here. The inclusions in the main-stage quartz grains of vein- and veinlet-style ores have two end-members $\left(>30 \% \mathrm{~V}_{\mathrm{CO} 2}\right.$ type II-l inclusions and $>50 \% \mathrm{~V}_{\mathrm{CO} 2}$ type II-g inclusions), rather than a continuum of compositions, suggesting that mixing of two separate fluids was not the primary cause for the coexisting of types 1 and 2 inclusions. All the fluid inclusions selected for microthermometry and laser Raman studies were primary in origin. They commonly developed in undeformed quartz grains, with regular shape and constant degrees of gas fill (Figure 5), without any evidence of necking down [57], indicating that the fluid-inclusion assemblage in the main stage quartz of vein- and veinlet-style ores were unaffected (or minimally affected) by post-entrapment deformation.

The initial homogeneous ore-forming fluids underwent fluid immiscibility during the main stage in the Sanshandao gold deposit, as evidenced by: (1) All the three types fluid inclusions appear in the same growth phase of the quartz (Figure $5 \mathrm{~g}-\mathrm{i}$ ), which shows that these FIs formed contemporaneously; (2) the total homogenization temperatures of type II inclusions are higher than those of aqueous inclusions (type III), and this also agrees with fluid immiscibility [64]; (3) the fluid salinity in the Sanshandao deposit shows a rising tend from the early stage to the main stage (Figure 9), consistent with fluid immiscibility (or phase separation) leading to higher salinity during evolution of the ore-forming liquid; (4) the type II-l inclusions and type II-g coexist as an isolated group, the type II-1 inclusions homogenized to the liquid, and some of type II-g inclusions with high $\mathrm{CO}_{2}$ phase(s) volumes homogenized to the vapor; and (5) two type II fluid inclusions with abnormal high density occur at about $300^{\circ} \mathrm{C}$ in the Sanshandao gold deposit (Figure 10). The density of these two fluid inclusions is obviously higher than that of the other inclusions. Together with their high homogenization pressures, this shows that $\mathrm{CO}_{2}$-rich overpressure fluid exists in the Sanshandao deposit, and the existence of 
such overpressure fluids is also likely to cause decompression boiling, which will also lead to fluid immiscibility. Finally, we think that fluid immiscibility was an important gold precipitation mechanism in the Sanshandao deposit.

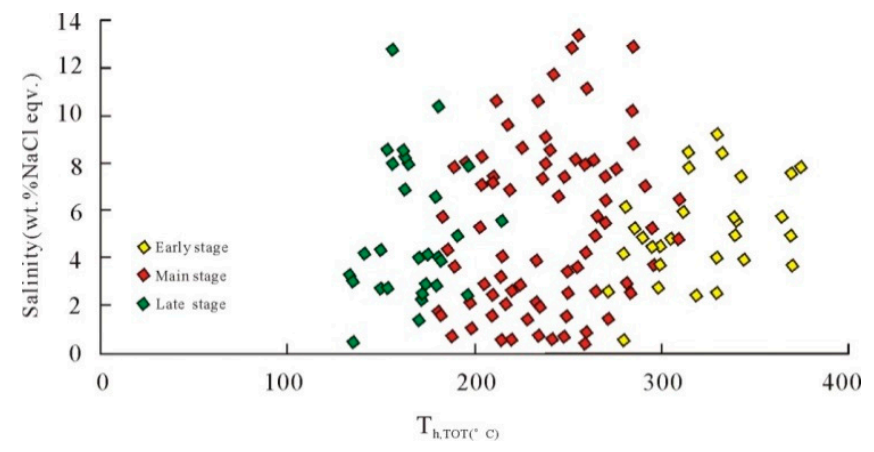

Figure 9. Evolution map of total homogenization temperatures $\left({ }^{\circ} \mathrm{C}\right)$ vs. salinity of the ore-forming fluid in the Sanshandao gold deposit.

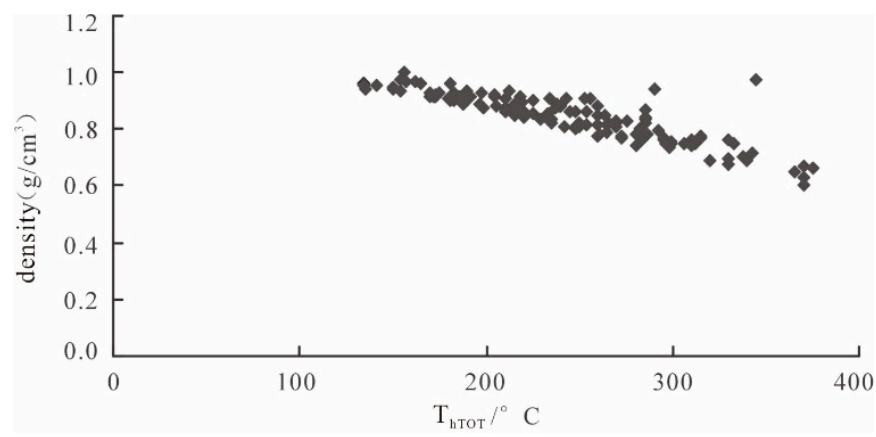

Figure 10. Evolution map of total homogenization temperatures $\left({ }^{\circ} \mathrm{C}\right)$ vs. density of the ore-forming fluid in the Sanshandao gold deposit.

\subsection{Source and Evolution of Ore-Forming Fluids}

\subsubsection{Source of Ore-Forming Fluids}

The $\delta^{18} \mathrm{O}$ and $\delta \mathrm{D}$ compositions of ore-forming fluids in the Sanshandao gold deposit are shown in Table 2 and Figure 11. The calculated $\delta^{18} \mathrm{O}_{\text {water }}$ values of ore-forming fluids vary from $0.97 \%$ to $10.79 \%$, with the median values decreasing from $7.45 \%$, to $5.5 \%$, to $1.36 \%$ from the early stage to late stage, respectively, indicating these calculations are not credible because the calculated $\delta^{18} \mathrm{O}_{\text {water }}$ values decreased from early stage to late stage mainly due to the decrease in equilibrium temperature, but the final homogenization temperature of fluid inclusions used for calculation is probably not the mineral-fluid equilibrium temperature [29]. Considering the similar median values of $\delta^{18} \mathrm{O}_{\mathrm{SMOW}}$ (quartz) for each hydrothermal stage (Table 3), the quartz in the four stages is probably deposited from the same fluid with a very constant $\delta^{18} \mathrm{O}$ composition. The $\delta \mathrm{D}$ values of the fluid inclusions in the quartz range from $-100 \%$ to $-48 \%$, with nearly constant median values from early stage to late stage. The calculated $\delta D_{\text {water }}$ values of hydrothermal waters in equilibrium with sericite are $\sim 30 \%$ less than that of the fluid inclusions in the quartz; thus, the reliability of these two results must be questioned. The single primary fluid inclusions being selected for microthermometry, different generations of fluid inclusions being trapped in quartz grains, and the large amount of secondary fluid inclusions probably caused the $\delta \mathrm{D}$ values of the hydrothermal fluids in each stage to be incorrect. By contrast, the sericite in the main stage was defined by detailed petrographic observation. Therefore, the calculated $\delta D_{\text {water }}$ values are more reliable. The most likely true $\delta^{18} \mathrm{O}$ and $\delta \mathrm{D}$ compositions of the primary ore-forming fluid in the Sanshandao gold deposit were calculated from quartz and sericite, respectively (Figure 11). 


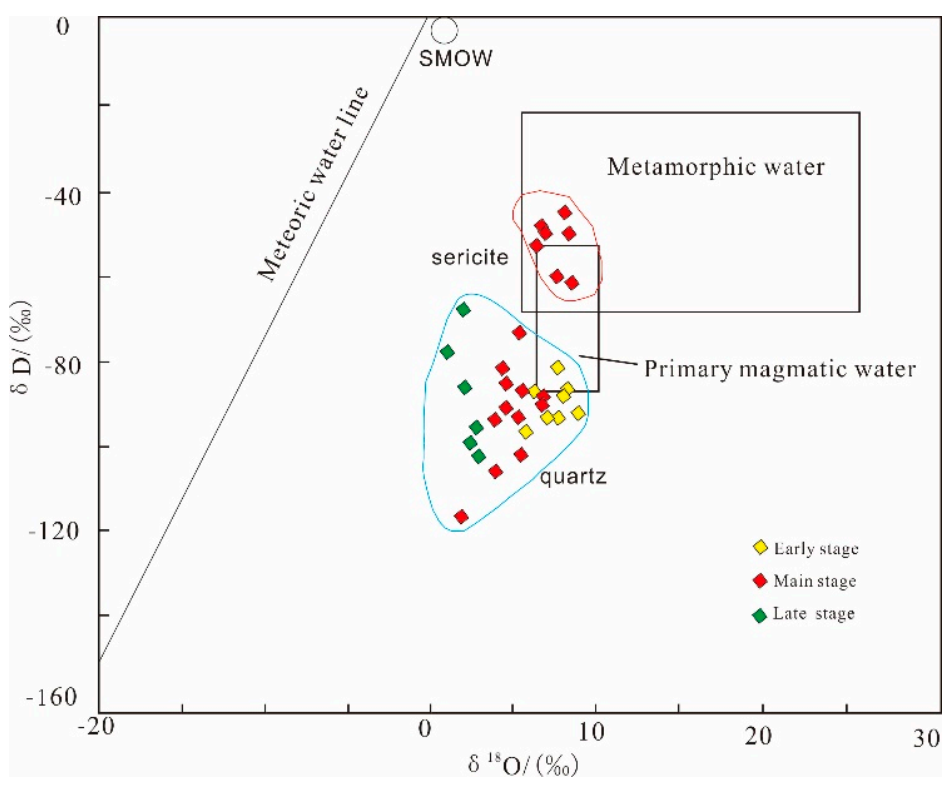

Figure 11. Isotopic compositions of oxygen and hydrogen in the Sanshandao gold deposit using data from Table 2. Blue circle and brown circles represent the data obtained from quartz and sericite, respectively.

Most of the data from sericite were recorded from the metamorphic water field, with some data from the field between metamorphic water and primary magmatic water. The ore-forming fluid of the Sanshandao gold deposit could have been derived from metamorphic fluid or primary magmatic water. The salinity of the ore-forming fluid in the Sanshandao deposit is generally lower $(<10 \%)$ than that of the magmatic-hydrothermal fluids. The low salinity $(<10$ eqv. wt $\% \mathrm{NaCl})$ is different from the normally high salinity magmatic-hydrothermal fluids [29,67]. All the FI homogenization temperatures of the ore-forming fluid are less than $500{ }^{\circ} \mathrm{C}$ in this study, which is also inconsistent with the property of magmatic-hydrothermal fluids [68]. Deng et al. [25] studied the stable isotopes $(\mathrm{H}-\mathrm{O}-\mathrm{C}-\mathrm{S}-\mathrm{Sr})$ in the Xinli gold deposit and revealed that $\delta \mathrm{D}_{\mathrm{SMOW}}$ and $\delta^{18} \mathrm{O}_{\mathrm{H} 2 \mathrm{O}}$ from the main stage are $-69.6 \%$ to $-88.3 \%$ and from $2.82 \%$ to $5.34 \%$, respectively; $\delta^{13} \mathrm{C}_{\mathrm{PDB}}$ and $\delta^{18} \mathrm{O}_{\mathrm{SMOW}}$ of late stage are from $-6.4 \%$ to $-2.4 \%$ and from $9.8 \%$ to $11.6 \%$, respectively; and $\delta^{34} \mathrm{~S}$ and ${ }^{87} \mathrm{Sr} /{ }^{86} \mathrm{Sr}$ ratios are from $9.42 \%$ to $11.62 \%$ and from 0.710657 to 0.711542 , respectively. They suggested that the ore-forming fluid genetically originated from the subducting slab and metasomatized mantle, akin to the magmatic water. Yang et al. [29] reported consistent stable isotopic (H-O-S) compositions and discussed their result for the Taishang gold deposit. Wang [28] studied the REE (rare earth element) composition of fluids in different mineralization stages in the Jiaojia gold field and found that the total REE content of metallogenic pyrite demonstrated a trend of first increasing and then decreasing from the early to late stage. This indicates that the metamorphism in the early stage is weak and strengthened in the main stage, then decreased again in the late stage. They combined evolution of the REE composition and $\mathrm{H}-\mathrm{O}$ isotope analysis also suggested that the ore-forming fluid originated from metamorphic water. As an exceptionally large fluid flux with a mixed $\mathrm{H}_{2} \mathrm{O}-\mathrm{CO}_{2}-\mathrm{CH}_{4}$ is required, the ore-forming fluid in the Sanshandao gold deposit probably had a metamorphic source.

The source of ore-forming fluids cannot be the Late Archean Jiaodong Group metamorphic rocks because the gold event occurred about 2 billion years later than the regional high-grade metamorphism. These components would have been lost from the rocks. As an exceptionally large fluid flux with a mixed $\mathrm{H}_{2} \mathrm{O}-\mathrm{CO}_{2}-\mathrm{CH}_{4}$ is required, the potential fluid reservoirs could be associated with the dehydration and decarbonization of the subducting Paleo-Pacific plate.

The $\delta^{34} \mathrm{~S}$ values of hydrothermal pyrite in the main stage have a narrow range, from $7.9 \%$ to $12.6 \%$ (Figure 8) with average of $10.25 \%$. These values are near or outside the upper ranges of the Linglong granite $(6.1 \% 0-10.1 \% 0)$ [35], Guojialing granite $(2.7 \% 0-10.0 \% 0)$ [29], Mesozoic intermediate-basic dykes 
(5.3\%o-10.8\%o) [12], and the Jingshan Group [68] (Figure 8), but higher than that of the metamorphic rocks in the Jiaodong Group [35] (7.2\%o-7.6\%) and the majority of lode gold deposits (Figure 8). The pyrite $\delta^{34} S$ from different sampling locations in the Sanshandao deposit are nearly invariable and consistent with other typical Jiaojia-type gold deposits. Similarly, in the Xinli gold deposit, the pyrites $\delta^{34} \mathrm{~S}$ display little variation [25]. The sulfur was suggested to be directly sourced from the Mesozoic granites, which probably scavenged the sulfur from the Jiaodong and Jingshan Groups $[18,69,70]$. Goldfarb and Santosh [6] ruled out the above argument on the basis of the evidence of the geological relationship and radiometric ages and proposed that the heavy sulfur could have been derived from the subducting marine sediments.

The enrichment of heavy sulfur isotopes is diagnostic of submarine exhalative deposits, the sulfur in which is mainly derived from non-bacterial reduction of isotopically heavy marine sulfate [71,72]. Zhu et al. [73] suggested that the heavy $S$ isotope signature of both deposit types in Jiaodong indicates that the sulfur was derived from the reduction of marine sulfate. The heavy $S$ isotope compositions originating from the reduction of seawater sulfate have been found in most sediment-hosted orogenic $\mathrm{Au}$ deposits, VHMS, and SEDEX $\mathrm{Cu}-\mathrm{Zn}-\mathrm{Pb}$ deposits [73-76]. However, the wall rocks of the Jiaodong gold deposits, dominated by Mesozoic granite and the Neoarchaean basement rocks, could not supply seawater sulfate, and the possibility of the heavy $S$ isotope being derived from recycled seawater in ore-forming fluids was also ruled out by the $\mathrm{H}-\mathrm{O}$ isotope compositions [17]. Considering the existence of many mafic dikes, which are associated with subduction of the Palaeo-Pacific plate nearly coeval with gold mineralization, sedimentary materials derived from the slab are a possible sulfur source. The possibility that the heavy sulfur could have been derived directly from evolved seawater is also worth considering.

Based on the $\mathrm{H}-\mathrm{O}-\mathrm{S}$ isotope analysis from this and previous studies [77-82], and given that an exceptionally large fluid flux with a mixed $\mathrm{H}_{2} \mathrm{O}-\mathrm{CO}_{2}-\mathrm{CH}_{4}$ is required, we think that the ore-forming fluids may be mainly associated with the dehydration and decarbonization of the subducting Paleo-Pacific plate, although devolatilization of a hydrated mantle wedge or subcontinental lithospheric mantle [6] cannot be excluded. Ore-forming materials bear both the mantle and the crustal fingerprints. This agrees with the subducted-related model proposed by Goldfarb and Santosh [6,83], and the sulfur was derived from subducted marine sediments.

\subsubsection{Evolution of Ore-Forming Fluids}

The evolutionary trend of ore fluid can be determined using the plot of homogenization temperature versus salinity [84]. The correlation between homogenization temperature and salinity of fluid inclusions trapped in fluid mixing is positive, and negative for fluid inclusions trapped in the process of fluid boiling or phase separation (Figure 9) [62]. According to fluid inclusion microthermometry and laser Raman spectroscopy, the dominant type II inclusions and subordinate type III inclusions developed in the early-stage quartz. Ore-forming fluids in this stage belong to $\mathrm{H}_{2} \mathrm{O}-\mathrm{CO}_{2}-\mathrm{NaCl}$ system, which has moderate-high temperatures, high $\mathrm{CO}_{2}$, and medium-to-low salinity (Figure 9). The water-rock reaction between metal-rich fluids and metamorphic rocks is a common process in each gold deposit (Water/Rock ratio of 0.1-0.5) [85], and the interaction was extensive at temperatures of $280-380{ }^{\circ} \mathrm{C}$ [85]. However, these temperatures coincide with the homogenization temperatures of early-stage FIs, in addition to widespread hydrothermal alteration in the early stage. The $\delta^{18} \mathrm{O}$ values of hydrothermal quartz are clearly different among the ores, altered rocks, and wall rocks, indicating that water-rock interactions were common during the early stages, significantly affecting the ore-forming fluid of the deposit. In the main stage, all three types of inclusions were identified, but still dominated by type II inclusions. The $\mathrm{CH}_{4}$ content in the carbonic phase increased dramatically, which led to the ore-forming system evolving from $\mathrm{H}_{2} \mathrm{O}-\mathrm{CO}_{2}-\mathrm{NaCl}$ to $\mathrm{H}_{2} \mathrm{O}-\mathrm{CO}_{2}-\mathrm{NaCl} \pm \mathrm{CH}_{4}$. As mineralization progressed, the ore-forming fluids moved upward through the faults and underwent water-rock reactions and fluid immiscibility, resulting in a large number of volatiles escaping, accompanied by increasing salinity and density of the ore fluids (Figures 9 and 10). 
Finally, the fluid evolved into an aqueous $\mathrm{H}_{2} \mathrm{O}-\mathrm{NaCl}$ system with low temperature, low salinity, high density, and no $\mathrm{CO}_{2}$ in the late stage.

\subsection{Mechanisms of Gold Deposition}

In hydrothermal solutions, gold is mainly dissolved and transported in the form of gold bisulfide complexes $\left(\mathrm{Au}(\mathrm{HS})_{2}{ }^{-}, \mathrm{Au}(\mathrm{HS})^{0}\right)$ and gold chloride complexes $\left(\mathrm{AuCl}_{2}{ }^{-}\right)$[86-90]. Given the close relationship between gold and sulfides (especially pyrite), both in the alteration zones and in the stockwork quartz veins. The ore fluids were near-neutral to weakly acidic [29,91], mostly characterized by low salinity ( $\leq 10 \mathrm{wt} \% \mathrm{NaCl}$ eqv.) and moderate temperature $\left(250-350{ }^{\circ} \mathrm{C}\right)$ at the Sanshandao gold deposit, we infer that $\mathrm{Au}(\mathrm{HS})_{2}{ }^{-}$was most probably the gold transporting complex at Sanshandao.

The FIs homogenization temperatures of the Sanshandao gold deposit range from 220 to $320^{\circ} \mathrm{C}$, following a normal distribution (Figure 6). This indicates that mineralization occurred under medium-temperature conditions. In terms of gold mineralization at Sanshandao, the disseminatedand stockwork-style ores are within the hydrothermal breccias and cataclastic zones. The echelon tensile auriferous veins developed in subsidiary faults, suggesting the continuous cycle of fluid pressure fluctuation associated with incremental rupture during fault zone movement [92]. Sibson et al. described the mechanism of fluid pressure cycling that probably occurred at Sanshandao, and it was significant due to the high angle of the fault veins (Figure 3). The cycle of fluid pressure build-up, failure, fluid pressure drop, and re-sealing by hydrothermal deposition [93] is apparent during vein formation at the Sanshandao gold deposit. The estimated pressures of the type II FIs are shown in Figure 12. The trapping pressures of the Sanshandao gold deposit from the early stage to the main stage are 165-200 MPa and 90-175 MPa, respectively, showing a gradual decrease during the evolution of the ore-forming fluids (Figure 12). Subsequently, large-scale fluid immiscibility occurred during the main stage of gold mineralization due to pressure fluctuation and temperature decrease. Along with fluid immiscibility, $\mathrm{H}_{2} \mathrm{~S}$ was fractionated strongly into the vapor phase and the activity of $\mathrm{HS}^{-}$lowered [94,95]. This process might have led to the decomposition of $\mathrm{Au}(\mathrm{HS})_{2}{ }^{-}$and the concomitant deposition of gold [96]. Fluid immiscibility can be caused via fluid-pressure cycling due to fault failure during development of the vein system [97]. Fluid-inclusion results indicate that, similar to other gold deposits in Jiaodong [98,99], fluid immiscibility caused by seismic movement along fault zones, lowered the gold-complex solubility are interpreted to be the major precipitation mechanism of gold deposition [29], especially for the vein- and veinlet-style ores [100,101].

Fluid-rock interaction was intensive in the Sanshandao gold deposit, which resulted in widespread hydrothermal alteration, especially sericitization, silicification, and pyritization. Iron entered the ore-forming fluid continuously during the reaction between ore-bearing fluids and iron-bearing wall-rock, resulting in the formation of pyrite, which would decrease the $\mathrm{H}_{2} \mathrm{~S}$ content of the fluid, then decrease the solubility of $\mathrm{Au}(\mathrm{HS})_{2}{ }^{-}$, thereby causing gold deposition [96,102-107]. Previous work indicated that minor gold was deposited during the early stage when no fluid immiscibility occurred, and gold has a close relationship with the widespread sulfidation, especially pyritization. All this suggests that the wall-rock sulfidation also played a role in gold deposition [29]. Abundant $\mathrm{CH}_{4}$ occurred in the main stage at the Sanshandao gold deposit (Figure 7) relative to other gold deposits in Jiaodong, and $\mathrm{CH}_{4}$ can expand the temperature and pressure range of fluid immiscibility and facilitate the occurrence of fluid immiscibility [91]. This can also contribute to the precipitation of gold. The appearance of $\mathrm{CH}_{4}$ indicates that the ore-forming fluid transformed into a more reducing fluid, which would cause $\mathrm{CO}_{2}$ to be reduced to $\mathrm{CH}_{4}$ and also cause gold precipitation. This is not a strong effect and is probably a second-order process for gold deposition. 

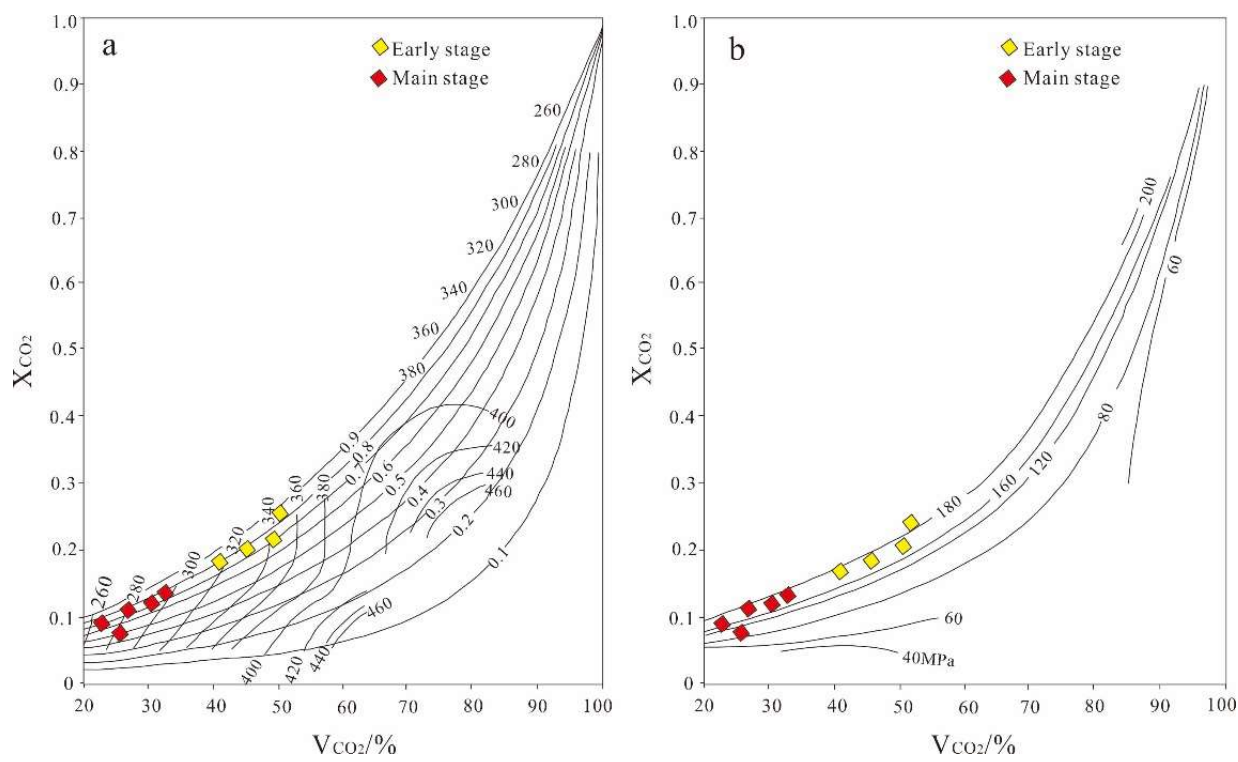

Figure 12. (a) Relationship of $\mathrm{X}_{\mathrm{CO} 2}, \mathrm{~V}_{\mathrm{CO} 2}$, and $\mathrm{CO}_{2}$ density, to $\mathrm{Th}_{\mathrm{TOT}}$ of the $\mathrm{CO}_{2}-\mathrm{H}_{2} \mathrm{O}-\mathrm{NaCl}$ fluid inclusions with salinity of $6.0 \mathrm{wt} \% \mathrm{NaCl}$ eqv. [108]. (b) Relationship of $\mathrm{X}_{\mathrm{CO} 2}, \mathrm{~V}_{\mathrm{CO} 2}$ to pressure of the $\mathrm{CO}_{2}-\mathrm{H}_{2} \mathrm{O}-\mathrm{NaCl}$ fluid inclusions with salinity of $6.0 \mathrm{wt} \% \mathrm{NaCl}$ eqv. [108]. $\mathrm{X}_{\mathrm{CO} 2}-\mathrm{Mole}$ fraction of $\mathrm{CO}_{2}$; $\mathrm{V}_{\mathrm{CO} 2}$ - Volume of $\mathrm{CO}_{2}$.

\section{Conclusions}

Three types of fluid inclusion were identified in the Sanshandao gold deposit: Type I pure $\mathrm{CO}_{2}$, type II aqueous-carbonic, and type III aqueous fluid inclusions. The type II fluid inclusions can be subdivided into gas-rich inclusions (II-g type) and aqueous-rich inclusions (II-1 type). The fluid-inclusion assemblage in the early stage mainly contains type II inclusions, whereas all three types of fluid inclusion coexist in the main stage quartz. In the late stage, only type III fluid inclusions were observed.

The ore-forming fluid was genetically derived from the subducting slab and metasomatized mantle. Ore-forming materials (gold and sulfur) were probably scavenged from the metasomatized mantle enriched with subduction-related components, predominantly originating from the Paleo-Pacific oceanic slab and its overlying sediments, which were thrust below the high-grade metamorphic rocks of the Jiaodong Peninsula. Both mantle and recycled crust components contributed ore-forming materials.

Gold was transported as the $\mathrm{Au}(\mathrm{HS})_{2}{ }^{-}$complex in hydrothermal solution at the Sanshandao gold deposit. Fluid immiscibility caused by episodic pressure drops due to fault movements, together with sulfidation and other physicochemical changes resulting from fluid-rock interactions, were the two main gold deposition mechanisms.

Author Contributions: L.Y. conceived and designed the ideas; Y.L., S.W., X.L., H.W. and B.C. participated in field investigation and photo processing; Y.L. performed the data curation, and writing-original draft preparation; L.Y. and Y.L. analyzed the data; Y.L. and L.Y. reviewed and edited the draft. D.L., P.W. and W.C provided help in the observation of fluid inclusions. All the data were obtained from previous work of the project team.

Funding: This Study was financially supported by the National Key Research Program of China (Grant No. 2016YFC0600107), the National Natural Science Foundation of China (Grant No. 41572069), the MOST Special Fund from the State Key Laboratory of Geological Processes and Mineral Resources, China University of Geosciences (Grant No. MSFGPMR201804), Key Laboratory of Gold Mineralization Processes and Resource Utilization Subordinated to the Ministry of Natural Resources and Key Laboratory of Metallogenic Geological Process and Resources Utilization in Shandong Province, Shandong Institute of Geological Sciences (Grant No. KFKT201801, KFKT201802), and the 111 Project under the Ministry of Education and the State Administration of Foreign Experts Affairs, China (Grant No. B07011). 
Acknowledgments: We thank to Kun Shen, who provided constructive comments on the fluid-inclusion experiment, as well as comments from Wei Shan and Min Li. We also thank Guangke Zhao and other staff from Sanshandao Gold Mine Corporation, as well as Jun Deng, Groves, Zhongliang Wang, Nan Li, Kunfeng Qiu and Liang Zhang for their help to improve the manuscript.

Conflicts of Interest: The authors declare no conflict of interest.

\section{References}

1. Deng, J.; Yang, L.Q.; Sun, Z.S.; Wang, J.P.; Wang, Q.F.; Xin, H.B.; Li, X.J. A metallogenic model of gold deposits of the Jiaodong granite green stone belt. Acta Geol. Sin. 2003, 77, 537-546.

2. Deng, J.; Yang, L.Q.; Li, R.H.; Groves, D.I.; Santosh, M.; Wang, Z.L.; Sai, S.X.; Wang, S.R. Regional structural control on the distribution of world-class gold deposits: An overview from the Giant Jiaodong Gold Province, China. Geol. J. 2018. [CrossRef]

3. Yang, L.Q.; Deng, J.; Wang, Q.F.; Zhou, Y.H. Coupling effects on gold mineralization of deep and shallow structures in the northwestern Jiaodong Peninsula, eastern China. Acta Geol. Sin. 2006, 80, 400-411.

4. Yang, L.Q.; Dilek, Y.; Wang, Z.L.; Weinberg, R.F.; Liu, Y. Late Jurassic, High Ba-Sr Linglong granites in the Jiaodong Peninsula, East China: Lower crustal melting products in the Eastern North China Craton. Geol. Mag. 2018, 155, 1040-1062. [CrossRef]

5. Groves, D.I.; Santosh, M. The giant Jiaodong gold province: The key to a unified model for orogenic gold deposits? Geosci. Front. 2016, 7, 409-417. [CrossRef]

6. Goldfarb, R.J.; Santosh, M. The dilemma of the Jiaodong gold deposits: Are they unique? Geosci. Front. 2014, 5, 139-153. [CrossRef]

7. Goldfarb, R.J.; Hart, C.J.R.; Davis, G.; Groves, D.I. East Asian gold-deciphering the anomaly of Phanerozoic gold in Precambrian cratons. Econ. Geol. 2007, 102, 341-346. [CrossRef]

8. Yang, L.Q.; Deng, J.; Guo, R.P.; Guo, L.N.; Wang, Z.L.; Chen, B.H.; Wang, X.D. World-class Xincheng gold deposit: An example from the giant Jiaodong Gold Province. Geosci. Front. 2016, 7, 419-430. [CrossRef]

9. Wang, Z.L.; Yang, L.Q.; Deng, J.; Santosh, M.; Zhang, H.F.; Liu, Y.; Li, R.H.; Huang, T.; Zheng, X.L.; Zhao, H. Gold-hosting high Ba-Sr granitoids in the Xincheng gold deposit, Jiaodong Peninsula, East China: Petrogenesis and tectonic setting. J. Asian Earth Sci. 2014, 95, 274-299. [CrossRef]

10. Deng, J.; Liu, X.F.; Wang, Q.F.; Pan, R.G. Origin of the Jiaodong-type Xinli gold deposit, Jiaodong Peninsula, China: Constraints from fluid inclusion and C-D-O-S-Sr isotope compositions. Ore Geol. Rev. 2014, 65, 674-686. [CrossRef]

11. Qiu, Y.M.; Groves, D.I.; McNaughton, N.J.; Wang, L.Z.; Zhou, T.H. Nature, age and tectonic setting of granitoid-hosted orogenic gold deposits of the Jiaodong Peninsula, eastern North China craton, China. Miner. Depos. 2002, 37, 283-305. [CrossRef]

12. Yang, L.Q.; Deng, J.; Wang, Z.L.; Zhang, L.; Guo, L.N.; Song, M.C.; Zheng, X.L. Mesozoic gold metallogenic system of the Jiaodong gold province, eastern China. Acta Petrol. Sin. 2014, 30, 2447-2467. (In Chinese with English Abstract).

13. Yang, L.Q.; Guo, L.N.; Wang, Z.L.; Zhao, R.X.; Song, M.C.; Zheng, X.L. Timing and mechanism of gold mineralization at the Wang'ershan gold deposit, Jiaodong Peninsula, eastern China. Ore Geol. Rev. 2017, 88, 491-510. [CrossRef]

14. Deng, J.; Wang, Q.F.; Wan, L.; Yang, L.Q.; Gong, Q.J.; Zhao, J.; Liu, H. Self-similar fractal analysis of gold mineralization of Dayingezhuang disseminated-veinlet deposit in Jiaodong gold province, China. J. Geochem. Explor. 2009, 102, 95-102. [CrossRef]

15. Deng, J.; Yang, L.Q.; Gao, B.F.; Sun, Z.S.; Guo, C.Y.; Wang, Q.F.; Wang, J.P. Fluid evolution and metallogenic dynamics during tectonic regime transition: Example from the Jiapigou gold belt in Northeast China. Resour. Geol. 2009, 59, 140-152. [CrossRef]

16. Fan, H.R.; Zhai, M.G.; Xie, Y.H.; Yang, J.H. Ore-forming fluids associated with granite hosted gold mineralization at the Sanshandao deposit, Jiaodong gold province, China. Miner. Depos. 2003, 38, 739-750. [CrossRef]

17. Li, S.R.; Santosh, M. Metallogeny and craton destruction: Records from the North China Craton. Ore Geol. Rev. 2014, 56, 376-414. [CrossRef] 
18. Tan, J.; Wei, J.H.; Audétat, A.; Pettke, T. Source of metals in the Guocheng gold deposit, Jiaodong Peninsula, North China Craton: Link to early Cretaceous mafic magmatism originating from Paleoproterozoic metasomatized lithospheric mantle. Ore Geol. Rev. 2012, 48, 70-87. [CrossRef]

19. Wang, L.; Sun, F.Y.; Wang, J.L. Geochemical features of ore-forming fluids of the Jinling gold deposit, Shandong Province. Acta Petrol. Sin. 2010, 26, 3735-3744. (In Chinese with English Abstract).

20. Yang, L.Q.; Deng, J.; Goldfarb, R.J.; Zhang, J.; Gao, B.F.; Wang, Z.L. 40Ar/39Ar geochronological constraints on the formation of the Dayingezhuang gold deposit: New implications for timing and duration of hydrothermal activity in the Jiaodong gold province, China. Gonwana Res. 2014, 25, 1469-1483. [CrossRef]

21. Zhang, L.; Li, G.W.; Zheng, X.L.; An, P.; Chen, B.Y. Tectonic-thermal history of Sanshandao gold deposit in eastern Jiaodong: Constraints of 40Ar/39Ar and fission track chronology. Acta Petrol. Sin. 2016, 32, 2465-2476. (In Chinese with English Abstract).

22. Zhai, M.G.; Yang, J.H.; Liu, W.J. Large clusters of gold deposits and large-scale metallogenesis in the Jiaodong Peninsula of Eastern China. Sci. China Ser. D 2001, 44, 758-768. [CrossRef]

23. Groves, D.I.; Goldfarb, R.J.; Robert, F.; Hart, C.J.R. Gold deposits in metamorphic belts: Overview of current understanding, outstanding problems, future research, and exploration significance. Econ. Geol. 2003, 98, 1-29.

24. Mao, J.W.; Wang, Y.T.; Li, H.M.; Pirajno, F.; Zhang, C.Q.; Wang, R.T. The relationship of mantle-derived fluids to gold metallogenesis in the Jiaodong Peninsula: Evidence from D-O-C-S isotope systematics. Ore Geol. Rev. 2008, 33, 361-381. [CrossRef]

25. Deng, J.; Wang, C.M.; Bagas, L.; Carranza, E.J.M.; Lu, Y.J. Cretaceous-Cenozoic tectonic history of the Jiaojia Fault and gold mineralization in the Jiaodong Peninsula, China: Constraints from zircon U-Pb, illite K-Ar and apatite fission track thermochronometry. Miner. Depos. 2015, 50, 987-1006. [CrossRef]

26. Chen, G.Y.; Shao, W.; Sun, D.S. Genetic Mineralogy of Gold Deposits in Jiaodong Region with Emphasis on Gold Prospecting; Chongqing Publishing House: Chongqing, China, 1989; pp. 181-224. (In Chinese with English Abstract).

27. Zhang, L.; Yang, L.Q.; Wang, Y.; Weinberg, R.F.; An, P.; Chen, B.Y. Thermochronologic constrains on the processes of formation and exhumation of the Xinli orogenic gold deposit, Jiaodong Peninsula, eastern China. Ore Geol. Rev. 2017, 81, 140-153. [CrossRef]

28. Goldfarb, R.J.; Groves, D.I.; Gardoll, S. Orogenic gold and geological time: A synthesis. Ore Geol. Rev. 2001, 18, 1-75. [CrossRef]

29. Deng, J.; Yuan, W.; Carranza, E.J.; Yang, L.; Wang, C.; Yang, L.; Hao, N. Geochronology and thermochronometry of the Jiapigou gold belt, northeastern China: New evidence for multiple episodes of mineralization. J. Asian Earth Sci. 2014, 89, 10-27. [CrossRef]

30. Zhang, X.O.; Cawood, P.A.; Wilde, S.A.; Liu, R.Q.; Song, H.L.; Li, W.; Snee, L.W. Geology and timing of mineralization at the Cangshang gold deposit, north-western Jiaodong Peninsula, China. Miner. Depos. 2003, 38, 141-153. [CrossRef]

31. Wang, Z.L.; Yang, L.Q.; Guo, L.N.; Marsh, E.; Wang, J.P.; Liu, Y.; Zhang, C.; Li, R.H.; Zhang, L.; Zheng, X.L.; et al. Fluid immiscibility and gold deposition in the Xincheng deposit, Jiaodong Peninsula, China: A fluid inclusion study. Ore Geol. Rev. 2015, 65, 701-717. [CrossRef]

32. Yang, L.Q.; Deng, J.; Guo, L.N.; Li, J.L. Origin and evolution of ore fluid, and gold deposition processes at the giant Taishang gold deposit, Jiaodong Peninsula, eastern China. Ore Geol. Rev. 2016, 72, 585-602. [CrossRef]

33. Deng, J.; Wang, Q.F.; Wan, L.; Liu, H.; Yang, L.Q.; Zhang, J. A mutifractal analysis of mineralization characteristics of the Dayinggezhuang disseminated-veinlet gold deposit in the Jiaodong gold province of China. Ore Geol. Rev. 2011, 40, 54-64. [CrossRef]

34. Mao, J.W.; Li, H.M.; Wang, Y.T.; Zhang, C.Q.; Wang, R.T. The relationship between mantle-derived fluid and gold ore-formation in the Eastern Shandong Peninsula: Evidences from D-O-C-S isotopes. Acta Geol. Sin. 2005, 79, 839-857. (In Chinese with English Abstract).

35. Brown, P.E. Fluid inclusion modeling for hydrothermal systems. Rev. Econ. Geol. 1998, 10, 151-171.

36. Uemoto, T.; Ridely, J.; Mikucki, E.; Groves, D.I. Fluid chemical evolution as a factor in controlling the distribution of gold at the Archean Golden Crown lode gold deposit, Murchison Province, Western Australia. Econ. Geol. 2002, 97, 1227-1248. [CrossRef]

37. Dugdale, A.L.; Hagemann, S.G. The Bronzewing lode gold deposit, eastern Australia: P-T-X evidence for fluid immiscibility caused by cyclic decompression in goldbearing quartz-veins. Chem. Geol. 2001, 173, 59-90. [CrossRef] 
38. Hagemann, S.G.; Luders, V. P-T-X conditions of hydrothermal fluids and precipitation mechanism of stibnite-gold mineralization at the Wiluna lode-gold deposits, Western Australia: Conventional and infrared microthermometric constraints. Mineral. Deposita 2003, 38, 936-952. [CrossRef]

39. Hu, S.X. Petrology of Metasomatic Rocks and Implications for Ore Exploration; Science Press: Beijing, China, 2002; pp. 1-264. (In Chinese)

40. Bodnar, R.J.; Vityk, M.O. Interpretation of microthermometric data for $\mathrm{H}_{2} \mathrm{O}-\mathrm{NaCl}$ fluid inclusions. In Fluid Inclusions in Minerals: Methods and Applications; de Vivo, B., Frezzotti, M.L., Eds.; Verginia Tech: Blacksburg, VA, USA, 1994; pp. 117-130.

41. Deng, J.; Liu, X.F.; Wang, Q.F.; Dilek, Y.; Liang, Y.Y. Isotopic Characterization and Petrogenetic Modeling of the Early Cretaceous Mafic Diking-Lithospheric Extension in the North China craton, eastern Asia. GSA Bull. 2017, 129, 1379-1407. [CrossRef]

42. Faure, M.; Lin, W.; Monie, P.; Breton, N.L.; Poussineau, S.; Panis, D.; Deloule, E. Exhumation tectonics of the ultrahigh-pressure metamorphic rocks in the Qinling orogen in east China: New petrological-structural-radiometric insights from the Shandong Peninsula. Tectonics 2003, 22, 1018-1040. [CrossRef]

43. Tang, J.; Zheng, Y.F.; Wu, Y.B.; Gong, B.; Zha, X.P.; Liu, X.M. Zircon u-pb age and geochemical constraints on the tectonic affinity of the Jiaodong terrane in the Sulu orogen, China. Precambrian Res. 2008, 161, 389-418. [CrossRef]

44. Zhai, M.G.; Bian, A.G.; Zhao, T.P. The amalgamation of the supercontinent of north China craton at the end of Neo-archaean and its breakup during late Palaeoproterozoic and Mesoproterozoic. Sci. China Earth Sci. 2000, 43, 219-232. [CrossRef]

45. Li, Q.L.; Chen, F.; Wang, X.L.; Li, X.H.; Li, C.F. Ultra-low procedural blank and the single-grain mica $\mathrm{Rb}-\mathrm{Sr}$ isochron dating. Chin. Sci. Bull. 2005, 50, 2861-2865.

46. Zhang, J.; Zhao, Z.F.; Zheng, Y.F.; Dai, M. Postcollisional magmatism: Geochemical constraints on the petrogenesis of Mesozoic granitoids in the Sulu orogen, China. Lithos 2010, 119, 512-536. [CrossRef]

47. Yang, L.Q.; Deng, J.; Wang, Z.L.; Guo, L.N.; Li, R.H.; Groves, D.I.; Danyushevskiy, L.; Zhang, C.; Zheng, X.L.; Zhao, H. Relationships between gold and pyrite at the Xincheng gold deposit, Jiaodong Peninsula, China: Implications for gold source and deposition in a brittle epizonal environment. Econ. Geol. 2016, 111, 105-126. [CrossRef]

48. Jiang, N.; Chen, J.; Guo, J.; Chang, G. In situ zircon U-Pb, oxygen and hafnium isotopic compositions of Jurassic granites from the North China craton: Evidence for Triassic subduction of continental crust and subsequent metamorphism-related $18 \mathrm{O}$ depletion. Lithos 2012, 142, 84-94. [CrossRef]

49. Yang, L.Q.; Deng, J.; Wang, Z.L.; Zhang, L.; Goldfarb, R.J.; Yuan, W.M.; Weinberg, R.F.; Zhang, R.Z. Thermochronologic constraints on evolution of the Linglong Metamorphic Core Complex and implications for gold mineralization: A case study from the Xiadian gold deposit, Jiaodong Peninsula, eastern China. Ore Geol. Rev. 2016, 72, 165-178. [CrossRef]

50. Liu, Y.; Deng, J.; Wang, Z.L.; Zhang, L.; Zhang, C.; Liu, X.D.; Zheng, X.L.; Wang, X.D. Zircon U-Pb age, Lu-Hf isotopes and petrogeochemistry of the monzogranites from Xincheng gold deposit, northwestern Jiaodong Peninsula, China. Acta Petrol. Sin. 2014, 30, 2559-2573. (In Chinese with English Abstract).

51. Hou, M.L.; Jiang, Y.H.; Jiang, S.Y.; Ling, H.F.; Zhao, K.D. Contrasting origins of late Mesozoic adakitic granitoids from the northwestern Jiaodong Peninsula, East China: Implications for crustal thickening to delamination. Geol. Mag. 2007, 144, 619-631. [CrossRef]

52. Goss, S.C.; Wilde, S.A.; Wu, F.; Yang, J. The age, isotopic signature and significance of the youngest Mesozoic granitoids in the Jiaodong terrane, Shandong province, North China craton. Lithos 2010, 3, 309-326. [CrossRef]

53. Yang, L.Q.; Deng, J.; Wang, Z.L. Ore-controlling structural pattern of Jiaodong gold deposits: Geologicalgeophysical integration constraints. In The Deep-Seated Structures of Earth in China; Chen, Y., Jin, Z., Shi, Y., Yang, W., Zhu, R., Eds.; Sciences Press: Beijing, China, 2014; pp. 1006-1030.

54. Faure, M.; Lin, W.; Chen, Y. Is the Jurassic (Yanshanian) intraplate tectonics of North China due to westward indentation of the North China block? Terra Nova 2012, 24, 456-466. [CrossRef]

55. Zhu, G.; Niu, M.L.; Xie, C.L.; Wang, Y.S. Sinistral to normal faulting along the Tan-Lu fault zone: Evidence for geodynamic switching of the East China continental margin. J. Geol. 2010, 118, 277-293. [CrossRef]

56. Collins, P.L.F. Gas hydrates in $\mathrm{CO}_{2}$-bearing fluid inclusions and use freezing data for estimation of salinity. Econ. Geol. 1979, 74, 1435-1444. [CrossRef] 
57. Bakker, R.J.; Jansen, J.B.H. A mechanism for preferential $\mathrm{H}_{2} \mathrm{O}$ leakage from fluid inclusions in quartz, based on TEM observations. Contrib. Mineral. Petrol. 1994, 116, 7-20. [CrossRef]

58. Brown, P.E.; Hagemann, S.G. MacFlincor and its application to fluids in Archaean lode-gold deposits. Geochim. Cosmochim. Acta 1995, 59, 3943-3952. [CrossRef]

59. Liu, H.B.; Jin, G.S.; Li, J.J.; Han, J.; Zhang, J.F.; Zhang, J.; Zhong, F.W.; Guo, D.Q. Determination of stable isotope composition in uranium geological samples. World Nucl. Geosci. 2013, 3, 174-179.

60. Roedder, E. Fluid inclusions. Rev. Mineral. 1984, 12, 1-664.

61. Clayton, R.N.; O'Neil, J.R.; Mayeda, T.K. Oxygen isotope exchange between quartz and water. J. Geophys. Res. 1972, 77, 3057-3067. [CrossRef]

62. Li, X.M. Studies and implications of the oxygen, hydrogen and carbon stable isotopes of the Sanshandao gold deposit, Shandong province. Contrib. Geol. Miner. Resour. Res. 1988, 3, 62-71. (In Chinese)

63. Zhang, L.G.; Chen, Z.S.; Liu, J.X.; Yu, G.X.; Wang, B.C.; Xu, J.F.; Zheng, W.S. Water-Rock Exchange in Jiaojia Type Gold Deposit: Hydrogen and Oxygen Isotope Composition of Ore-forming Fluids. Miner. Depos. 1994, 13, 193-200. (In Chinese)

64. Wang, Y.W.; Zhu, F.S.; Gong, R.T. Tectonic isotope geochemistry-Restudy of sulfur isotope in Jiaodong gold province. Gold 2002, 23, 1-16. (In Chinese)

65. Huang, D.Y. Sulfur Isotope Study of Metallogenic Series of Jiaodong Gold Deposit. Miner. Depos. 1994, 13, 75-87. (In Chinese)

66. Xavier, R.P.; Foster, R.P. Fluid evolution and chemical controls in the FazendaMaria Preta (FMP) gold deposit, Rio Itapicuru greenstone belt, Bahia, Brazil. Chem. Geol. 1999, 154, 133-154. [CrossRef]

67. Rusk, B.G.; Reed, M.H.; Dilles, J.H. Fluid inclusion evidence for magmatic- hydrothermal fluid evolution in the porphyry copper-molybdenum deposit at butte, Montana. Econ. Geol. 2008, 103, 307-334. [CrossRef]

68. Goldfarb, R.J.; Groves, D.I. Orogenic gold: Common or evolving fluid and metal sources through time. Lithos 2015, 233, 2-26. [CrossRef]

69. Li, Y.P. The genesis of the Rushan gold deposits in east Shandong. Miner. Depos. 1992, 11, 165-172. (In Chinese with English Abstract).

70. Luo, Z.K.; Miao, L.C. Granites and Gold Deposits in Zhaoyuan-Laizhou Area, Eastern Shandong Province; Metallurgical Industry Press: Beijing, China, 2002; pp. 84-117. (In Chinese with English Abstract).

71. Ohmoto, H.; Rye, R. Isotopes of sulfur and carbon. In Geochemistry of Hydrothermal Ore Deposits, 2nd ed.; Bernes, H.L., Ed.; John Wiley and Sons: New York, NY, USA, 1979; pp. 509-567.

72. Zhong, R.C.; Li, W.B. The multistage genesis of the giant Dongshengmiao Zn-Pb-Cu deposit in western Inner Mongolia, China: Syngenetic stratabound mineralization and metamorphic remobilization. Geosci. Front. 2016, 7, 529-542. [CrossRef]

73. Zhu, Z.Y.; Jiang, S.Y.; Ryan, M.; Cook, N.J.; Yang, T.; Wang, M.L.; Ma Ciobanu, C.L. Iron isotope behavior during fluid/rock interaction in K-feldspar alteration zone-A model for pyrite in gold deposits from the Jiaodong Peninsula, East China. Geochim. Cosmochim. Acta 2018, 222, 94-116. [CrossRef]

74. Sangster, D.F. Relative sulphur isotope abundances of ancient seas and strata-bound sulphide deposits. Proc. Geol. Assoc. Can. 1968, 17, 79-91.

75. Goodfellow, W.D.; Lydon, J.W.; Turner, R. Geology and genesis of stratiform sediment-hosted (SEDEX) zinc-lead silver sulphide deposits. Geol. Assoc. Can. Spec. Pap. 1993, 40, 1-25.

76. Huston, D.L. Stable isotopes and their significance for understanding the genesis of volcanic-hosted massive sulfide deposits: A review. Rev. Econ. Geol. 1999, 8, 157-179.

77. Roedder, E. Fluid Inclusions as Samples of Ore Fluids. In Geochemistry of Hydrothermal Ore Deposits, 2nd ed.; Wiley: New York, NY, USA, 1979; pp. 684-737.

78. Gui, F.; Wang, L.; Ma, F. Study on Fluid Inclusions in Sanshandao Gold Deposit. Gold 2014, 35, $27-32$. (In Chinese with English Abstract).

79. Shepherd, T.J.; Rankin, A.H.; Alderton, D.H.M. A Practical Guide to Fluid Inclusion Studies; Blackie \& Son Limited: Glasgow, UK; London, UK, 1985; pp. 1-154.

80. Anderson, M.R.; Rankin, A.H.; Spiro, B. Fluid mixing in the generation of isothermal gold mineralization in the Transvaal Sequence, Transvaal, South Africa. Eur. J. Mineral. 1992, 4, 933-948. [CrossRef]

81. Yang, M.Z. The Geochemistry of Wallrock Alteration Zone of Gold Deposits-As Exemplified by Jiaodong Gold Deposits; Geological Publishing House: Beijing, China, 1998; pp. 1-120. (In Chinese) 
82. Li, H.Q.; Liu, J.Q.; Wei, L. Chronological Study of Fluid Inclusion for Hydrothermal Deposit and Its Geological Applications; Geological Publishing House: Beijing, China, 1993; pp. 1-126. (In Chinese)

83. Deng, J.; Wang, Q.F. Gold mineralization in China: Metallogenic provinces, deposit types and tectonic framework. Gondwana Res. 2016, 36, 219-274. [CrossRef]

84. Zhai, D.G.; Liu, J.J.; Wang, J.P.; Yang, Y.Q.; Liu, X.W.; Wang, G.W.; Liu, Z.J.; Wang, X.L.; Zhang, Q.B. Characteristics of melt-fluid inclusions and sulfur isotopic compositions of the Hashitu molybdenum deposit, Inner Mongolia. Earth Sci. J. China Univ. Geosci. 2012, 37, 1279-1290. (In Chinese with English Abstract).

85. Yang, L.Y.; Yang, L.Q.; Yuan, W.M.; Zhang, C.; Zhao, K.; Yu, H.J. Origin and evolution of ore fluid for orogenic gold traced by D-O isotopes: A case from the Jiapigou gold belt, China. Acta Petrol. Sin. 2013, 29, 4025-4035. (In Chinese with English Abstract).

86. Seward, T.M. Thio complexes of gold and the transport of gold in hydrothermal ore solutions. Geochim. Cosmochim. Acta 1973, 37, 379-399. [CrossRef]

87. Seward, T.M. The Hydrothermal Geochemistry of Gold, Gold Metallogeny and Exploration; Springer: New York, NY, USA, 1990; pp. 37-62.

88. Hayashi, K.I.; Ohmoto, H. Solubility of gold in NaCl- and H2S-bearing aqueous olutions at $250-350{ }^{\circ} \mathrm{C}$. Geochim. Cosmochim. Acta 1991, 55, 2111-2126. [CrossRef]

89. Gammons, C.H.; Williams-Jones, A.E.; Yu, Y. New data on the stability of gold I) chloride complexes at $300{ }^{\circ}$ C. Mineral. Mag. A 1994, 58, 309-310. [CrossRef]

90. Benning, L.G.; Seward, T.M. Hydrosulphide complexing of gold (I) in hydrothermal solutions from 150 to $500{ }^{\circ} \mathrm{C}$ and 500 to 1500 bars. Geochim. Cosmochim. Acta 1996, 60, 849-1871. [CrossRef]

91. Yang, L.Q.; Badal, J. Mirror symmetry of the crust in the oil/gas region of Shengli, China. J. Asian Earth Sci. 2013, 78, 327-344. [CrossRef]

92. Cox, S.F. Faulting processes at high uid pressures: An example of fault valve behaviour from the Wattle Gully Fault, Victoria, Australia. J. Geophys. Res. 1995, 100, 12841-12859. [CrossRef]

93. Sibson, R.H.; Robert, F.; Poulsen, K.H. High angle reverse faults, uid-pressure cycling, and mesothermal gold-quartz deposits. Geology 1988, 16, 551-555. [CrossRef]

94. Naden, J.; Shepherd, T.J. Role of methane and carbon dioxide in gold depositions. Nature 1989, 342, 793-795. [CrossRef]

95. Cox, S.F.; Sun, S.S.; Etheridge, M.A.; Wall, V.J.; Potter, T.F. Structural and geochemical controls on the development of turbidite-hosted gold quartz vein deposits, Wattle Gully mine, central Victoria, Australia. Econ. Geol. 1995, 90, 1722-1746. [CrossRef]

96. Mikucki, E.J. Hydrothermal transport and depositional processes in Archean lode gold systems: A review. Ore Geol. Rev. 1998, 13, 307-321. [CrossRef]

97. Wilkinson, J.J.; Johnston, J.D. Pressure fluctuations, phase separation, and gold precipitation during seismic fracture propagation. Geology 1996, 24, 395-398. [CrossRef]

98. Yang, L.Q.; Deng, J.; Guo, C.Y.; Zhang, J.; Jiang, S.Q.; Gao, B.F.; Gong, Q.J.; Wang, Q.F. Ore-forming fluid characteristics of the Dayingezhuang gold deposit, Jiaodong gold province, China. Resour. Geol. 2009, 59, 182-195. [CrossRef]

99. Qiu, K.F.; Marsh, E.; Yu, H.C.; Pfaff, K.; Gulbransen, C.; Gou, Z.Y.; Li, N. Fluid and metal sources of the Wenquan porphyry molybdenum deposit, Western Qinling, NW China. Ore Geol. Rev. 2017, 86, 459-473. [CrossRef]

100. Qiu, K.F.; Deng, J.; Taylor, R.D.; Song, K.R.; Song, Y.H.; Li, Q.Z.; Goldfarb, R.J. Paleozoic magmatism and porphyry Cu-mineralization in an evolving tectonic setting in the North Qilian Orogenic Belt, NW China. J. Asian Earth Sci. 2016, 122, 20-40. [CrossRef]

101. Yang, Q.Y.; Santosh, M.; Shen, J.F.; Li, S.R. Juvenile vs. recycled crust in NE China: Zircon U-Pb geochronology, Hf isotope and an integrated model for Mesozoic gold mineralization in the Jiaodong Peninsula. Gondwana Res. 2014, 25, 1445-1468. [CrossRef]

102. Yang, L.Q.; Deng, J.; Qiu, K.F.; Ji, X.Z.; Santosh, M.; Song, K.R.; Song, Y.H.; Geng, J.Z.; Zhang, C.; Hua, B. Magma mixing and crust mantle interaction in the Triassic monzogranites of Bikou Terrane, central China: Constraints from petrology, geochemistry, and zircon $\mathrm{U}-\mathrm{Pb}-\mathrm{Hf}$ isotopic systematic. J. Asian Earth Sci. 2015, 98, 320-341. [CrossRef] 
103. Qiu, K.F.; Taylor, R.D.; Song, Y.H.; Yu, H.C.; Song, K.R.; Li, N. Geologic and geochemical insights into the formation of the Taiyangshan porphyry copper-molybdenum deposit, Western Qinling Orogenic Belt, China. Gondwana Res. 2016, 35, 40-58. [CrossRef]

104. Yang, L.Q.; Deng, J.; Dilek, Y.; Qiu, K.F.; Ji, X.Z.; Li, N.; Taylor, R.D.; Yu, J.Y. Structure, Geochronology, and Petrogenesis of the Late Triassic Puziba Granitoid Dikes in the Mianlue Suture Zone, Qinling Orogen, China. GSA Bulletin 2015, 127, 1831-1854. [CrossRef]

105. Qiu, K.F.; Deng, J. Petrogenesis of granitoids in the Dewulu skarn copper deposit: implications for the evolution of the Paleotethys ocean and mineralization in Western Qinling, China. Ore Geol. Rev. 2017, 90, 1078-1098. [CrossRef]

106. Groves, D.I.; Phillips, G.; Ho, S.E.; Houstoun, S.M. The nature, genesis and regional controls of gold mineralization in Archaean greenstone belts of the Western Australian Shield; a brief review. S. Afr. J. Geol. 1985, 88, 135-148.

107. Qiu, K.F.; Song, K.R.; Song, Y.H. Magmatic-hydrothermal fluid evolution of the Wenquan porphyry molybdenum deposit in the north margin of the Western Qinling, China. Acta Petrol. Sin. 2015, 31, 3391-3404. (In Chinese with English Abstract).

108. Schwartz, M.O. Determining phase volumes of mixed $\mathrm{CO}_{2}-\mathrm{H}_{2} \mathrm{O}$ inclusions using microthermetric measurements. Miner. Depos. 1989, 24, 43-47. [CrossRef]

(c) 2019 by the authors. Licensee MDPI, Basel, Switzerland. This article is an open access article distributed under the terms and conditions of the Creative Commons Attribution (CC BY) license (http:/ / creativecommons.org/licenses/by/4.0/). 